\title{
问

\section{Transformation of Char Carbon During Bubbling Fluidized Bed Gasification of Biomass}

Kevin Timmer

Dordt College, kevin.timmer@dordt.edu

Robert C. Brown

lowa State University

Follow this and additional works at: https://digitalcollections.dordt.edu/faculty_work

Part of the Petroleum Engineering Commons

\section{Recommended Citation}

Timmer, K., \& Brown, R. C. (2019). Transformation of Char Carbon During Bubbling Fluidized Bed Gasification of Biomass. Fuel, 242, 837. https://doi.org/10.1016/j.fuel.2019.01.039

This Article is brought to you for free and open access by Dordt Digital Collections. It has been accepted for inclusion in Faculty Work Comprehensive List by an authorized administrator of Dordt Digital Collections. For more information, please contact ingrid.mulder@dordt.edu. 


\title{
Transformation of Char Carbon During Bubbling Fluidized Bed Gasification of Biomass
}

\begin{abstract}
This study focuses on the fate of carbon in the char generated by devolatilization of biomass during fluidized bed gasification. A carbon balance model was developed to distinguish between char transformed to carbon-bearing gases and its comminution and elutriation as fine char during gasification. The model accurately predicts the transient accumulation of char carbon in the reactor. Experiments revealed steady state reactor char carbon loadings were achieved after multiple hours of gasification. The model formed the basis of an experimental methodology that assesses the transformation of char carbon based on collection of elutriated solids from the reactor and assessment of the steady state char carbon loading in the reactor. Experiments were performed to distinguish the relative contributions of chemical reaction and physical comminution toward conversion of char to gaseous and solid products. The effects of equivalence ratio, gasification temperature, superficial gas velocity, biomass particle size, and the addition of steam on the partitioning of char carbon between gaseous and solid products during gasification of ground seed corn in a bubbling fluidized bed were investigated. This study revealed that char conversion during gasification of biomass was limited by elutriation of fine char particles arising from fragmentation or attrition of primary char product. Additionally, increased chemical reaction of char to form gases was usually accompanied by increased elutriation of fine char, which suggests that chemical reaction increased the porosity of the char and its susceptibility to fragmentation and attrition. Finally, decreasing superficial gas velocity, increasing equivalence ratio, and decreasing particle size led to increased carbon conversion, while increasing temperature and steam concentration in the reactor had negligible effect.
\end{abstract}

\section{Keywords}

biomass gasification, carbon balance, fluidized bed, char conversion, comminution, chemically enhanced attrition

\section{Disciplines}

Petroleum Engineering

\section{Comments}

Online article access information:

https://www.sciencedirect.com/science/article/pii/S0016236119300390 
Transformation of char carbon during bubbling fluidized bed gasification of biomass

Kevin J. Timmer ${ }^{\mathrm{a}, 1}$ and Robert C. Brown ${ }^{\mathrm{b}}$

a (Corresponding author), Black Engineering, Iowa State University, Ames, IA 50011, USA; e-mail: Kevin.Timmer@dordt.edu; Declaration of Interests: None

${ }^{\mathrm{b}}$ Center for Sustainable Environmental Technologies, Iowa State University, 1140 BRL, Ames, IA 50011, USA; e-mail: rcbrown3@iastate.edu; Declaration of Interests: None

\begin{abstract}
This study focuses on the fate of carbon in the char generated by devolatilization of biomass during fluidized bed gasification. A carbon balance model was developed to distinguish between char transformed to carbon-bearing gases and its comminution and elutriation as fine char during gasification. The model accurately predicts the transient accumulation of char carbon in the reactor. Experiments revealed steady state reactor char carbon loadings were achieved after multiple hours of gasification. The model formed the basis of an experimental methodology that assesses the transformation of char carbon based on collection of elutriated solids from the reactor and assessment of the steady state char carbon loading in the reactor. Experiments were performed to distinguish the relative contributions of chemical reaction and physical comminution toward conversion of char to gaseous and solid products. The effects of equivalence ratio, gasification temperature, superficial gas velocity, biomass particle size, and the addition of steam on the partitioning of char carbon between gaseous and solid products during gasification of ground seed corn in a bubbling fluidized bed were investigated. This study revealed that char conversion during gasification of biomass was limited by elutriation of fine char particles arising from fragmentation or attrition of primary char product. Additionally, increased chemical reaction of char to form gases was usually accompanied by increased elutriation of fine char, which suggests that chemical reaction increased the porosity of the char and its susceptibility to fragmentation and attrition. Finally, decreasing superficial gas velocity, increasing equivalence ratio, and decreasing particle size led to increased carbon conversion, while increasing temperature and steam concentration in the reactor had negligible effect.
\end{abstract}


Keywords: biomass gasification; carbon balance; fluidized bed; char conversion; comminution; chemically enhanced attrition

${ }^{1}$ Present address: $4984^{\text {th }}$ Ave NE, Sioux Center, IA 51250, USA; e-mail: Kevin.Timmer@dordt.edu

\section{Introduction}

The physical and chemical processes that control the partitioning of carbon between gas and solid products during biomass gasification are not well understood. Gasification of biomass in a fluidized bed reactor is often limited by incomplete conversion of char to carbon-bearing gases due to loss through comminution to fine particles that elutriate from the reactor. Equilibrium thermodynamic calculations [1]-[8] indicate that carbon in char should be completely transformed into gases at typical gasification operating conditions, but most biomass gasifiers produce significant char co-product [1], [9]-[30].

The overall yield of carbon-bearing gases is defined as the fraction of the fuel carbon that is converted to gas, vapor, or aerosol form. A majority of the biomass carbon leaves the reactor transformed as carbon monoxide $(\mathrm{CO})$, carbon dioxide $\left(\mathrm{CO}_{2}\right)$, methane $\left(\mathrm{CH}_{4}\right)$, and elutriable char with smaller contributions from other light hydrocarbons and tar (condensable organic compounds).

Efforts to improve the yield of carbon-bearing gases from char have focused on enhancing gas-solid reactions of oxygen and steam with char. Yield of these gases increases with increasing equivalence ratio (ER) [1], [9], [11]-[15], [21], [23], [28]. However, increasing ER beyond an optimum level lowers the caloric content of the produced gas [1], [7], [10], [11], [21], [24], [28], [31], [32]. Attempts to improve the yield of carbon in the gaseous products leaving fluidized bed gasifiers through addition of steam [12], [20], [21], [24], [30] or operation at higher temperatures [1], [9], [11], [13], [14], [16]-[22], [30] have met with limited success.

The study of carbon conversion to gaseous products during fluidized bed gasification is complicated by the fact that char carbon undergoes both chemical reaction and physical comminution. Devolatilization of biomass and gas-solid reactions of char contribute to production of carbonaceous gases while fragmentation and elutriation of char reduce gas yield. Carbon balances on fluidized beds must account for these different forms of carbon. The goal of the present study was to measure char 
conversion during fluidized bed gasification and relate it to important operating parameters including equivalence ratio, reaction temperature, superficial gas velocity, biomass particle size, and the addition of steam. Towards this end, a carbon balance model was developed to distinguish between char transformed to carbon-bearing gases and its comminution and elutriation as fine char during gasification. This model was used to analyze experimental data obtained from a laboratory-scale fluidized bed gasifier and determine rates of transformation of char to gas or attrition to elutriable fines as a function of operating conditions.

\section{Theory and calculations}

A carbon balance model was devised to distinguish between char conversion to carbon-bearing gases and its comminution and elutriation as fine solids. Char carbon is defined as residual solid carbon remaining after devolatilization of biomass in the fluidized bed. This is different from fixed carbon determined by ASTM proximate analysis (ASTM Standard E 870-82). The amount of carbon remaining in the char after devolatilization of biomass depends on particle temperature and heating rate [27], [29], [32]-[45], which are likely to be different during fluidized bed gasification than the conditions of ASTM proximate analysis.

As illustrated in Figure 1, the rate of accumulation of char carbon in the reactor, $\mathrm{dW}_{\mathrm{c}} / \mathrm{dt}$, is the sum of the rate at which it is generated by devolatilization of biomass, G; the rate that it is elutriated as fine solid from the gasifier, $\mathrm{R}_{\mathrm{e}}$; and the rate at which it is converted to carbon-bearing gases due to chemical reaction, $\mathrm{R}_{\mathrm{r}}$ :

$$
\frac{\mathrm{dW}_{\mathrm{c}}}{\mathrm{dt}}=\mathrm{G}-\mathrm{R}_{\mathrm{e}}-\mathrm{R}_{\mathrm{r}}
$$




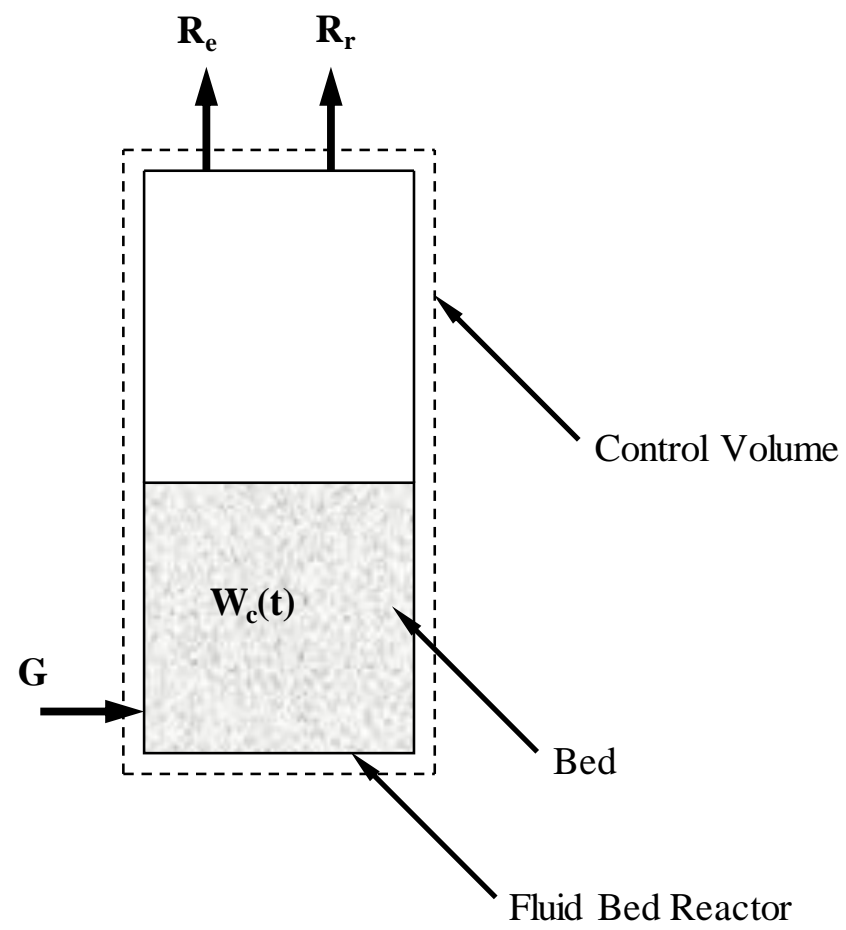

$\mathbf{W}_{\mathbf{c}}=$ char carbon loading in the reactor $(\mathrm{g})$

$\mathbf{G}=$ char carbon generation rate $(\mathrm{g} / \mathrm{s})$

$\mathbf{R}_{\mathbf{e}}=$ char carbon elutriation rate $(\mathrm{g} / \mathrm{s})$

$\mathbf{R}_{\mathbf{r}}=$ char carbon chemical reaction rate $(\mathrm{g} / \mathrm{s})$

Figure 1. Control volume used for determining the mass balance of char carbon during biomass gasification

The char carbon generation rate due to biomass devolatilization, $\mathrm{G}$, is a function of the feed rate of biomass into the gasifier, $\mathrm{F}$, and the fraction of biomass that is converted into char carbon, $\mathrm{f}_{\mathrm{c}}$ :

$$
\mathrm{G}=\mathrm{f}_{\mathrm{c}} \mathrm{F}
$$

As subsequently demonstrated by experiment, $\mathrm{f}_{\mathrm{c}}$ is a function of devolatilization temperature.

During operation at fixed conditions the elutriation rate is proportional to the mass of char carbon in the reactor [46], [47]:

$$
\mathrm{R}_{\mathrm{e}}=\mathrm{k}_{\mathrm{e}} \mathrm{W}_{\mathrm{c}}
$$

where $\mathrm{k}_{\mathrm{e}}\left(\mathrm{s}^{-1}\right)$ is the char carbon elutriation rate coefficient.

The chemical reaction rate is assumed to be first order with respect to the amount of char carbon present: 


$$
\mathrm{R}_{\mathrm{r}}=\mathrm{k}_{\mathrm{r}} \mathrm{W}_{\mathrm{c}}
$$

where $\mathrm{k}_{\mathrm{r}}\left(\mathrm{s}^{-1}\right)$ is the gas-solid chemical reaction rate coefficient.

The total char carbon removal rate $\left(\mathrm{R}_{\mathrm{t}}\right)$ from the gasifier is the sum of the removal rates by chemical reaction and elutriation:

$$
\mathrm{R}_{\mathrm{t}}=\mathrm{k}_{\mathrm{e}} \mathrm{W}_{\mathrm{c}}+\mathrm{k}_{\mathrm{r}} \mathrm{W}_{\mathrm{c}}=\mathrm{k}_{\mathrm{t}} \mathrm{W}_{\mathrm{c}}
$$

where $\mathrm{k}_{\mathrm{t}}$ is the total char carbon removal rate coefficient. Substituting Eq. (5) into Eq. (1) gives:

$$
\frac{\mathrm{dW}_{\mathrm{c}}}{\mathrm{dt}}=\mathrm{G}-\mathrm{k}_{\mathrm{t}} \mathrm{W}_{\mathrm{c}}
$$

While gasifying under fixed operating conditions, including temperature, $\mathrm{k}_{\mathrm{e}}, \mathrm{k}_{\mathrm{r}}$, and $\mathrm{k}_{\mathrm{t}}$ are expected to remain essentially constant. Therefore, separating variables and integrating yields:

$$
\mathrm{W}_{\mathrm{c}}(\mathrm{t})=\frac{\mathrm{G}}{\mathrm{k}_{\mathrm{t}}}\left[1-\exp \left(-\mathrm{k}_{\mathrm{t}} \mathrm{t}\right)\right]
$$

which predicts the mass of char carbon in the reactor at any time, $t$. At large times $\left(t=t_{s s}\right)$ a steady state carbon loading in the reactor, $\mathrm{W}_{\mathrm{c}}\left(\mathrm{t}_{\mathrm{ss}}\right)$, is approached. At steady state, Eq. (7) can be rearranged to:

$$
\mathrm{k}_{\mathrm{t}}=\frac{\mathrm{G}}{\mathrm{W}_{\mathrm{c}}\left(\mathrm{t}_{\mathrm{ss}}\right)}
$$

\section{Material and methods}

\subsection{Gasifier and gas/char sampling system}

Experiments were performed in a laboratory scale $\left(10 \mathrm{~kW}_{\text {th }}\right)$ atmospheric bubbling fluidized bed gasifier, illustrated in Figure 2. The flow of air into the reactor was controlled by a mass flow controller and was preheated by a star-wound cable heater located in the plenum section. The main reaction chamber was constructed of two flanged Inconnel 625 pipes. The $9.53 \mathrm{~cm}$ diameter lower section was $81.3 \mathrm{~cm}$ long while the $15.2 \mathrm{~cm}$ diameter upper portion was $122 \mathrm{~cm}$ in length. Temperatures in the reactor were controlled independent of ER with a series of high temperature semi-cylindrical ceramic fiber guard heaters that encase the gasifier. The fluidization media consisted of a mixture of $70 \mathrm{wt} \%$ silica sand with a mass weighted average diameter of $0.321 \mathrm{~mm}$ and $30 \mathrm{wt} \%$ calcined limestone of a total mass of approximately $2000 \mathrm{~g}$. The calcined limestone reacted with alkali released from the biomass to 
mitigate against ash slagging and agglomeration of bed material [48], [49]. The minimum fluidization velocity of the bed was measured to be $2.06 \mathrm{~cm} / \mathrm{s}$ at $700^{\circ} \mathrm{C}$. As shown in Figure 2, a precision metering auger fed biomass from the hopper perpendicularly into a high speed injection auger connected to the fluidized bed reactor.

The product gas stream from the gasifier exited through a cyclone particulate separator before being sampled isokinetically. As illustrated in Figure 2, the gas sampling system consisted of a stainless steel probe inserted in the gas flow, a heated quartz fiber thimble filter to collect particulate matter, an ice bath impinger train to remove tar and water, a diaphragm vacuum pump to induce flow through the sampling system, a rotameter and valve to adjust the gas flow appropriate to isokinetic sampling requirements, a dry test meter to accurately measure the total flow volume over the course of an experiment, and a micro gas chromatograph (GC) for measuring concentrations of $\mathrm{N}_{2}, \mathrm{O}_{2}, \mathrm{H}_{2}, \mathrm{CO}, \mathrm{CO}_{2}, \mathrm{C}_{2} \mathrm{H}_{2}, \mathrm{C}_{2} \mathrm{H}_{4}$, and $\mathrm{C}_{2} \mathrm{H}_{6}$. To prevent condensation of tar the temperature of the cyclone particulate separator, the exhaust piping, and a portion of the sample system were maintained above $450^{\circ} \mathrm{C}$ with electrical resistance heating tape.

Discarded seed corn was employed as a model biomass fuel because it was easy to work with, fed consistently, and its low ash content helped reduce the accumulation of alkali in the fluidized bed, prolonging the bed's useful life. Table 1 gives the proximate and ultimate analysis of the ground seed corn as reported by Hazen Research Inc., Golden, Colorado. The moisture content of the ground seed corn varied between $11.2-13.1 \%$, averaging $12.0 \%$ across the experiments. Whole kernel seed corn was reduced using a portable agricultural feed grinder to two different particle size distributions. The coarse grind produced particles with an average mass weighted diameter of $1.9 \mathrm{~mm}$ based on sieve data, while the fine grind produced $0.96 \mathrm{~mm}$ diameter particles on average. 


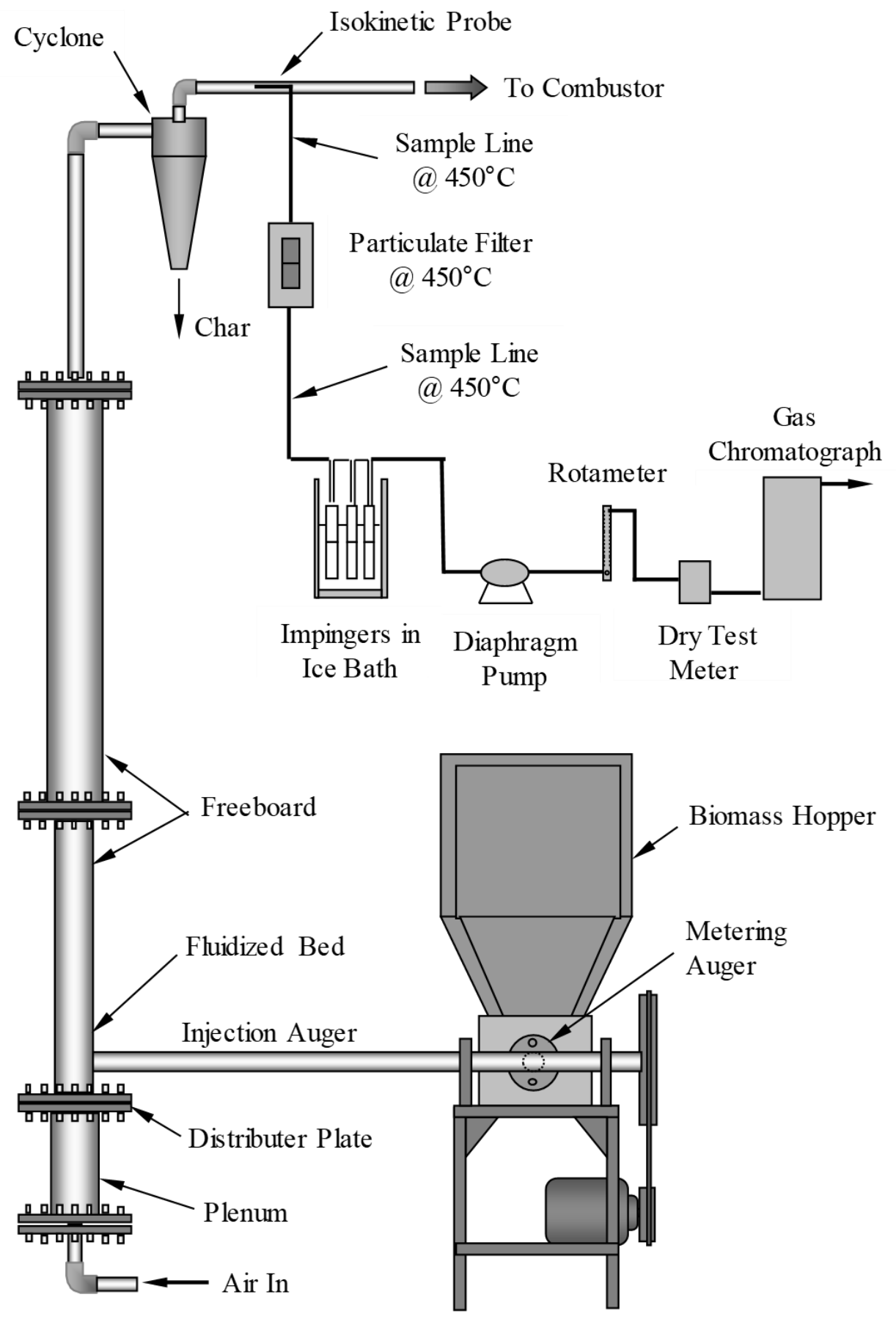

Figure 2. Schematic of gasifier with sample systems (note: for clarity ceramic guard heaters surrounding the plenum, bed, and freeboard are not shown) 
Table 1. Proximate and ultimate analysis of ground seed corn

\begin{tabular}{ccc}
\hline & $\begin{array}{c}\text { Biomass } \\
\text { Component }\end{array}$ & $\begin{array}{c}\text { Ground Seed Corn } \\
(\% \text { wt, dry })\end{array}$ \\
\hline \hline \multirow{2}{*}{ Proximate } & Volatile & 86.44 \\
& Fixed Carbon & 11.77 \\
& Ash & 1.79 \\
\hline Ultimate & $\mathrm{C}$ & 48.91 \\
& $\mathrm{H}$ & 5.95 \\
& $\mathrm{O}$ & 41.46 \\
$\mathrm{~N}$ & 1.73 \\
$\mathrm{~S}$ & 0.16 \\
& Ash & 1.79 \\
\hline
\end{tabular}

\subsection{Experimental procedures}

\subsubsection{Biomass feed rate}

The ground seed corn was fed into the fluidized bed using a dual auger system as shown in Figure 2. At the conclusion of an experiment the average feed rate was calculated as the quantity of biomass gasified divided by the duration of the experiment.

\subsubsection{Steady state experiments}

Steady state experiments were performed at temperatures between $700-800^{\circ} \mathrm{C}$ and with ER values between $0.24-0.37$. While steady temperatures in the reactor were typically achieved a few minutes after the biomass feed was initiated, true steady state gasification required establishment of the asymptotic char carbon loading in the unit, which required up to several hours of operation under some conditions (see Figure 4 for examples of carbon loading vs. time profiles).

Biomass feed rate was set to achieve the desired ER for the specified air flow rate. The ceramic guard heaters surrounding the reactor were used to control the temperature in the reactor independent of the ER value. The concentration of water vapor in the reactor was increased for some experiments by injecting wet steam into the bottom of the bed during gasification.

The steady state char carbon elutriation rate, $\mathrm{R}_{\mathrm{e}}\left(\mathrm{t}_{\mathrm{ss}}\right)$ was determined using the cyclone catch and thimble filter catch. After establishing steady state gasification the cyclone catch can was removed and 
replaced with a clean, pre-weighed catch can. Elutriated char was captured by the cyclone and collected in the can over a measured length of time (typically $30-60 \mathrm{~min}$ ) to give an adequate sample.

Concurrently, an isokinetic sample of the producer gas downstream of the cyclone was drawn through a clean, pre-weighed quartz thimble filter. After the sampling period the cyclone catch and thimble filter were recovered and weighed. The average residence time of the char carbon in the reactor was sufficiently long in these experiments $(20-70 \mathrm{~min})$ to complete pyrolysis of the biomass [45]. Therefore the collected char was assumed to be composed of carbon and ash. Consequently, the carbon content of the cyclone catch and thimble filter catch was assessed as the mass lost after combustion in a bench top furnace. The cyclone catch was used to estimate the mass of char carbon in the coarse particulate matter leaving the gasifier. The thimble filter data was used in conjunction with the total volume of the isokinetic gas sample to estimate the mass of char carbon in the fine particulate matter remaining in the producer gas after passing through the cyclone. The steady state elutriation rate, $\mathrm{R}_{\mathrm{e}}\left(\mathrm{t}_{\mathrm{ss}}\right)$, was calculated as the sum of the fine and coarse char carbon collected divided by the sample time period. The total carbon gas yield, $\mathrm{Y}_{\mathrm{tc}}$, is the fraction of carbon entering the reactor, both fixed and volatile, converted to a gas or aerosol:

$$
\mathrm{Y}_{\mathrm{tc}}=1-\frac{\mathrm{R}_{\mathrm{e}}\left(t_{\mathrm{ss}}\right)}{\dot{m}_{\mathrm{c}, \mathrm{b}}}
$$

where $\dot{m}_{\mathrm{c}, \mathrm{b}}$ is the mass flow of carbon entering with the biomass, calculated as a product of the biomass feed rate and the mass fraction of carbon in the biomass as given in Table 1. Note that this method of calculating total carbon yield does not require measurement of the tar present in the product gas stream.

Experiments were concluded by "burning out the reactor" to determine the mass loading of char carbon in the reactor during steady state operation, $\mathrm{W}_{\mathrm{c}}\left(\mathrm{t}_{\mathrm{ss}}\right)$. Burnout was initiated by discontinuing the biomass feed while maintaining the air flow. During burnout the flow of gaseous carbon leaving the reactor was monitored using a micro GC to record the concentrations of the carbonaceous gases in the product stream. The cyclone and thimble filters were used as describe previously in this section to determine the quantity of char carbon that elutriated during burnout. Steady state char carbon loading in 
the reactor was determined as the sum of the carbonaceous gas profiles integrated in time and the char carbon elutriated during burnout.

Measurement of $\mathrm{R}_{\mathrm{e}}\left(\mathrm{t}_{\mathrm{ss}}\right)$ and $\mathrm{W}_{\mathrm{c}}\left(\mathrm{t}_{\mathrm{ss}}\right)$ allowed calculation of the elutriation rate coefficient by rearrangement of Eq. (3):

$$
\mathrm{k}_{\mathrm{e}}=\frac{\mathrm{R}_{\mathrm{e}}\left(\mathrm{t}_{\mathrm{ss}}\right)}{\mathrm{W}_{\mathrm{c}}\left(\mathrm{t}_{\mathrm{ss}}\right)}
$$

The value of $\mathrm{k}_{\mathrm{t}}$ was found using Eq. (8) and the chemical reaction rate coefficient, $\mathrm{k}_{\mathrm{r}}$, was calculated by difference:

$$
\mathrm{k}_{\mathrm{r}}=\mathrm{k}_{\mathrm{t}}-\mathrm{k}_{\mathrm{e}}
$$

Comparisons of $\mathrm{k}_{\mathrm{e}}$ and $\mathrm{k}_{\mathrm{r}}$ as a function of operating conditions shed light on how the char carbon generated from the entering biomass was either transformed into a carbon-bearing gas or elutriated.

The gaseous carbon yield from char carbon, $\mathrm{Y}_{\mathrm{cc}}$, is defined as the fraction of the char carbon generated from the biomass that is converted to a carbon-bearing gas and is given by:

$$
\mathrm{Y}_{\mathrm{cc}}=1-\frac{\mathrm{R}_{\mathrm{e}}\left(\mathrm{t}_{\mathrm{ss}}\right)}{\mathrm{G}}
$$

\subsubsection{Char carbon fraction, $f_{c}$}

The char carbon generation rate, G, was determined as a fraction of the total biomass feed rate (Eq. (2)). The char carbon fraction, $\mathrm{f}_{\mathrm{c}}$, of ground seed corn was found experimentally as a function of temperature by injecting $10 \mathrm{~g}$ batch samples of ground corn into the gasifier bed fluidized with $\mathrm{N}_{2}$ and held at temperature with the ceramic guard heaters for 30 minutes to ensure complete devolatilization. After devolatilization of the sample, $\mathrm{f}_{\mathrm{c}}$ was determined by burning the carbon out of the reactor, integrating the carbon-bearing gas profiles in time, and combining that data with char carbon recovered from the cyclone catch and thimble filter as described in Section 3.2.2.

\subsubsection{Transient char carbon reactor loadings}

Transient char carbon reactor loadings were measured to compare to model predictions (Eq. (7)). Experiments were conducted by injecting biomass at constant rate into the pre-heated fluidized bed for the desired length of gasification time. The experiment concluded by discontinuing biomass feed and 
proceeding to burn out the reactor, while collecting elutriated char with the cyclone and thimble filters. The char carbon loading was determined as described in Section 3.2.2.

\subsubsection{Uncertainty analysis}

The uncertainty in experimentally measured parameters was conservatively estimated based on the limitations of the equipment and methodology employed and has been affirmed by replication of results. The uncertainty in calculated values was estimated using error propagation methods [50]. Uncertainty bars on data represent $95 \%$ confidence intervals. Note that in some instances the uncertainty bars are so small as to be obscured by the data markers.

\section{Results and discussion}

\section{$4.1 f_{c}$ vs. temperature}

The mass fraction of the biomass that remains as char carbon after devolatilization, $\mathrm{f}_{\mathrm{c}}$, depends on the gasification temperature. The char carbon fraction as a function of temperature was measured for ground seed corn using the method described in Section 3.2.3. The results of these experiments are given in Figure 3. Lines connecting the average of each of the three groups of data have been added to help clarify the relationship. The decreasing trend in the char carbon fraction with increasing temperature is consistent with published results [27], [29], [32]-[45], [51]. It should also be noted that a proximate analysis of the ground seed corn (Table 1) yielded a fixed carbon fraction of $11.77 \%$, which is within the range of the char carbon fractions measured here.

\subsection{Model validation}

The transient model of the char carbon loading in the reactor (Eq. (7)) was compared to experimental results at two different operating conditions. A model was constructed for each operating condition by calculating the char carbon generation rate using Eq. (2) and by experimentally measuring the steady state carbon loading in the reactor, $\mathrm{W}_{\mathrm{c}}\left(\mathrm{t}_{\mathrm{ss}}\right)$, as described in Section 3.2.2. These values where inserted into Eq. (8), and then Eq. (7), to create the transient model. Transient char carbon loadings were measured following the procedure described in Section 3.2.4 by stopping gasification at specified times before steady state conditions were achieved. The results of these experiments are given in Table 2. 


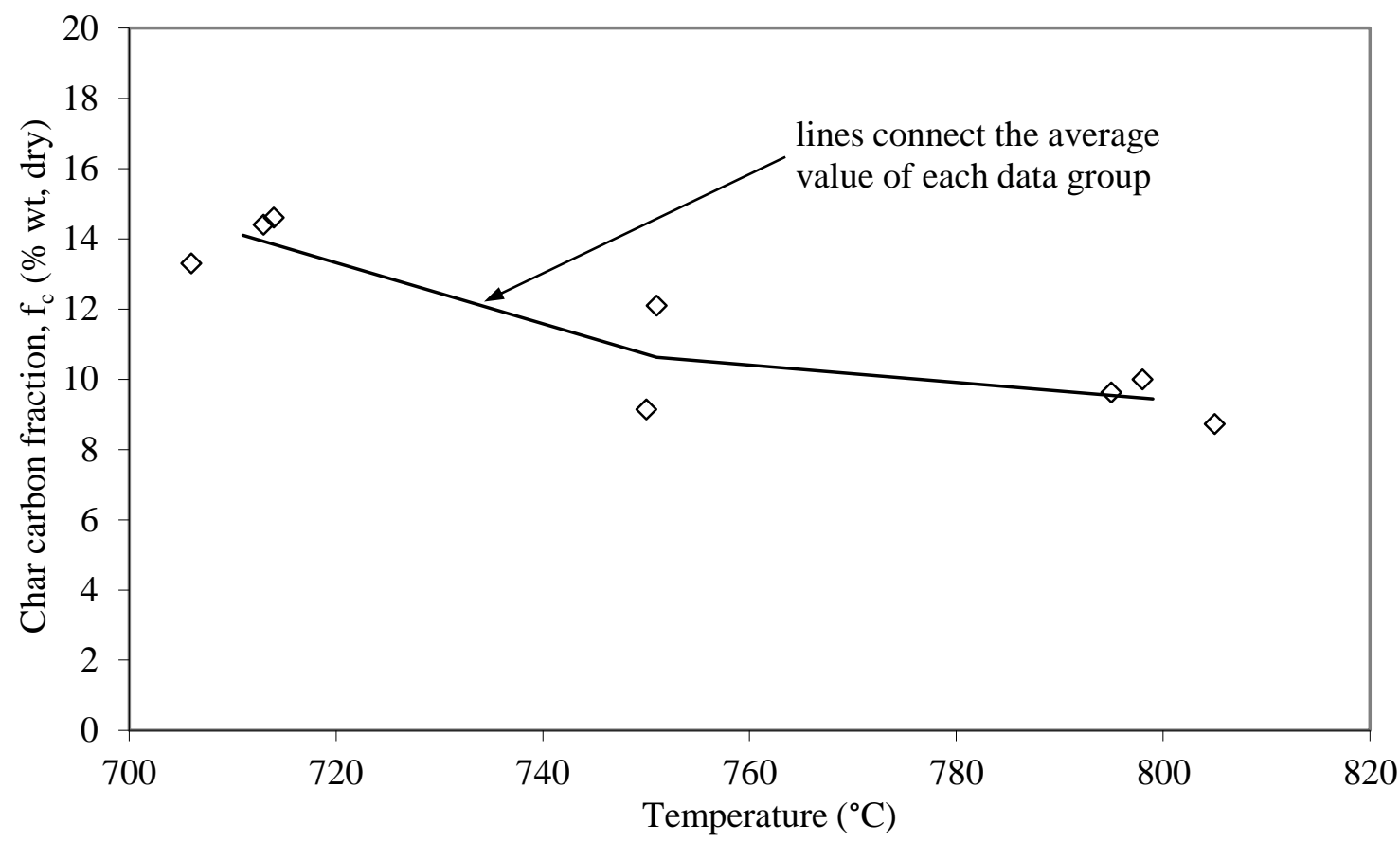

Figure 3. Char carbon fraction of devolatilized fine ground seed corn as a function of temperature. Gasifier was fluidized with nitrogen gas $(\mathrm{ER}=0)$

Figure 4 compares char carbon loadings in the fluidized bed vs. time for experiments (Experiments $a-j$ ) and model predictions (Eq. (7)) for gasification at $715^{\circ} \mathrm{C}$ and for two different equivalence ratios $(\mathrm{ER}=$ 0.27 and ER $=0.31$ ). The figure shows excellent agreement between the measured carbon loadings and those predicted by the model over time. The relatively large error bars at early times are due to uncertainty in the char carbon generation rate, $\mathrm{G}$, caused by temperature fluctuations in the gasifier corresponding to the introduction of biomass into the preheated bed.

\subsection{Steady state experiments}

While the char carbon balance model accurately predicted the buildup of char carbon in the reactor over time (see Section 4.2), it was primarily used to analyze steady state experiments using the method described in Section 3.2.2. The char carbon analysis methodology was applied to measurements made during gasification of ground seed corn at various operating conditions. Table 2 shows the operating parameters for each of the steady state experiments in this study. 
Table 2. Operating data and experimental results for gasification of ground seed corn

\begin{tabular}{|c|c|c|c|c|c|c|c|c|c|c|c|c|c|c|c|c|c|}
\hline Exp. & Type & $\begin{array}{c}\text { Time } \\
\text { Gasifying } \\
\text { (h) }\end{array}$ & $\begin{array}{c}\text { Feed } \\
\text { Rate } \\
\text { (g/s dry) }\end{array}$ & $\begin{array}{c}\text { Biomass } \\
\text { Size }\end{array}$ & $\mathrm{n}_{\mathrm{H} 2 \mathrm{O}} / \mathrm{n}_{\mathrm{cc}}$ & $\begin{array}{c}\text { Air } \\
\text { Flow } \\
\text { (slpm) }\end{array}$ & ER & Temp & $\begin{array}{c}\mathrm{f}_{\mathrm{c}} \\
\text { Figure } 4 \\
\text { (\%wt dry) }\end{array}$ & $(g / s)$ & $\mathrm{W}_{\mathrm{c}}$ & $(\mathrm{cm} / \mathrm{s})$ & $\left(10^{-3} \mathrm{~g} / \mathrm{s}\right)$ & $\left(10^{-6} \mathrm{~s}^{-1}\right)$ & $\left(10^{-6} \mathrm{~s}^{-1}\right)$ & $\mathrm{Y}_{\mathrm{cc}}$ & $\mathrm{Y}_{\mathrm{tc}}$ \\
\hline $\bar{a}$ & transient & 0.50 & 0.594 & Fine & 0.6 & 50.0 & 0.309 & 715 & 13.7 & 0.0810 & 77 & $\mathrm{n} / \mathrm{a}$ & $\mathrm{n} / \mathrm{a}$ & $\mathrm{n} / \mathrm{a}$ & $\mathrm{n} / \mathrm{a}$ & $\mathrm{n} / \mathrm{a}$ & $\mathrm{n} / \mathrm{a}$ \\
\hline$b$ & transient & 0.50 & 0.594 & Fine & 0.6 & 50.0 & 0.309 & 715 & 13.7 & 0.0810 & 103 & $\mathrm{n} / \mathrm{a}$ & $\mathrm{n} / \mathrm{a}$ & $\mathrm{n} / \mathrm{a}$ & $\mathrm{n} / \mathrm{a}$ & $\mathrm{n} / \mathrm{a}$ & $\mathrm{n} / \mathrm{a}$ \\
\hline$c$ & transient & 2.00 & 0.594 & Fine & 0.6 & 50.0 & 0.309 & 715 & 13.7 & 0.0810 & 136 & $\mathrm{n} / \mathrm{a}$ & $\mathrm{n} / \mathrm{a}$ & $\mathrm{n} / \mathrm{a}$ & $\mathrm{n} / \mathrm{a}$ & $\mathrm{n} / \mathrm{a}$ & $\mathrm{n} / \mathrm{a}$ \\
\hline$d$ & steady state & 4.50 & 0.594 & Fine & 0.6 & 50.0 & 0.309 & 715 & 13.7 & 0.0810 & 147 & $\mathrm{n} / \mathrm{a}$ & $\mathrm{n} / \mathrm{a}$ & $\mathrm{n} / \mathrm{a}$ & $\mathrm{n} / \mathrm{a}$ & $\mathrm{n} / \mathrm{a}$ & $\mathrm{n} / \mathrm{a}$ \\
\hline$e$ & transient & 0.50 & 0.654 & Fine & 0.6 & 50.0 & 0.279 & 715 & 13.7 & 0.0942 & 181 & $\mathrm{n} / \mathrm{a}$ & $\mathrm{n} / \mathrm{a}$ & $\mathrm{n} / \mathrm{a}$ & $\mathrm{n} / \mathrm{a}$ & $\mathrm{n} / \mathrm{a}$ & $\mathrm{n} / \mathrm{a}$ \\
\hline$f$ & transient & 1.50 & 0.654 & Fine & 0.6 & 50.0 & 0.279 & 715 & 13.7 & 0.0942 & 268 & $\mathrm{n} / \mathrm{a}$ & $\mathrm{n} / \mathrm{a}$ & $\mathrm{n} / \mathrm{a}$ & $\mathrm{n} / \mathrm{a}$ & $\mathrm{n} / \mathrm{a}$ & $\mathrm{n} / \mathrm{a}$ \\
\hline$g$ & transient & 2.50 & 0.654 & Fine & 0.6 & 50.0 & 0.279 & 715 & 13.7 & 0.0942 & 332 & $\mathrm{n} / \mathrm{a}$ & $\mathrm{n} / \mathrm{a}$ & $\mathrm{n} / \mathrm{a}$ & $\mathrm{n} / \mathrm{a}$ & $\mathrm{n} / \mathrm{a}$ & $\mathrm{n} / \mathrm{a}$ \\
\hline$h$ & transient & 4.50 & 0.658 & Fine & 0.6 & 50.0 & 0.277 & 715 & 13.7 & 0.0942 & 381 & $\mathrm{n} / \mathrm{a}$ & $\mathrm{n} / \mathrm{a}$ & $\mathrm{n} / \mathrm{a}$ & $\mathrm{n} / \mathrm{a}$ & $\mathrm{n} / \mathrm{a}$ & $\mathrm{n} / \mathrm{a}$ \\
\hline$i$ & steady state & 11.50 & 0.673 & Fine & 0.6 & 50.0 & 0.271 & 715 & 13.7 & 0.0942 & 401 & $\mathrm{n} / \mathrm{a}$ & $\mathrm{n} / \mathrm{a}$ & $\mathrm{n} / \mathrm{a}$ & $\mathrm{n} / \mathrm{a}$ & $\mathrm{n} / \mathrm{a}$ & $\mathrm{n} / \mathrm{a}$ \\
\hline$j$ & steady state & 11.55 & 0.672 & Fine & 0.6 & 50.0 & 0.271 & 714 & 13.8 & 0.0928 & 423 & 28 & 12.2 & 190 & 28.8 & 86.8 & 96.3 \\
\hline$k$ & steady state & 4.75 & 0.535 & Fine & 0.8 & 40.0 & 0.273 & 748 & 10.8 & 0.0578 & 146 & 21 & 3.66 & 371 & 25.1 & 93.7 & 98.6 \\
\hline$l$ & steady state & 5.50 & 0.609 & Fine & 0.8 & 50.0 & 0.300 & 748 & 10.8 & 0.0658 & 164 & 28 & 5.26 & 368 & 32.0 & 92 & 98.2 \\
\hline$m$ & steady state & 3.48 & 1.061 & Fine & 0.8 & 83.0 & 0.286 & 750 & 10.6 & 0.1124 & 202 & 49 & 19.8 & 459 & 98.2 & 82.4 & 96.2 \\
\hline$n$ & steady state & 8.00 & 0.754 & Fine & 1.0 & 50.0 & 0.242 & 801 & 9.5 & 0.0716 & 198 & 38 & 13.4 & 295 & 67.7 & 81.3 & 96.4 \\
\hline$o$ & steady state & 6.75 & 0.678 & Fine & 1.0 & 50.0 & 0.269 & 801 & 9.5 & 0.0644 & 142 & 35 & 8.01 & 397 & 56.3 & 87.6 & 97.6 \\
\hline$p$ & steady state & 4.33 & 0.493 & Fine & 1.0 & 50.0 & 0.370 & 805 & 9.4 & 0.0464 & 71 & 30 & 4.39 & 587 & 61.4 & 90.5 & 98.2 \\
\hline$q$ & steady state & 7.25 & 0.689 & Fine & 0.9 & 50.0 & 0.265 & 751 & 10.5 & 0.0724 & 325 & 31 & 11.0 & 189 & 34.0 & 84.7 & 96.7 \\
\hline$r$ & steady state & 6.87 & 0.689 & Fine & 0.9 & 50.0 & 0.265 & 751 & 10.5 & 0.0724 & 318 & 31 & 11.3 & 192 & 35.6 & 84.3 & 96.6 \\
\hline$s$ & steady state & 7.42 & 0.652 & Fine & 0.9 & 50.0 & 0.280 & 753 & 10.5 & 0.0684 & 258 & 30 & 9.40 & 229 & 36.4 & 86.3 & 97 \\
\hline$t$ & steady state & 6.00 & 0.540 & Fine & 0.9 & 50.0 & 0.338 & 750 & 10.6 & 0.0572 & 136 & 28 & 6.56 & 373 & 48.3 & 88.5 & 97.5 \\
\hline$u$ & steady state & 6.00 & 0.518 & Coarse & 0.9 & 50.0 & 0.282 & 746 & 11.0 & 0.0570 & 224 & 26 & 10.4 & 209 & 46.4 & 81.8 & 95.9 \\
\hline$v$ & steady state & 4.83 & 0.677 & Coarse & 0.9 & 50.0 & 0.270 & 801 & 9.5 & 0.0643 & 144 & 34 & 13.9 & 350 & 96.5 & 78.4 & 95.8 \\
\hline$w$ & steady state & 3.50 & 0.739 & Fine & 1.8 & 50.0 & 0.247 & 798 & 9.5 & 0.0702 & 111 & 36 & 12.0 & 524 & 108. & 82.9 & 96.7 \\
\hline$x$ & steady state & 3.25 & 0.724 & Fine & 2.9 & 50.0 & 0.252 & 797 & 9.5 & 0.0688 & 93 & 38 & 10.2 & 632 & 110. & 85.2 & 97.1 \\
\hline
\end{tabular}




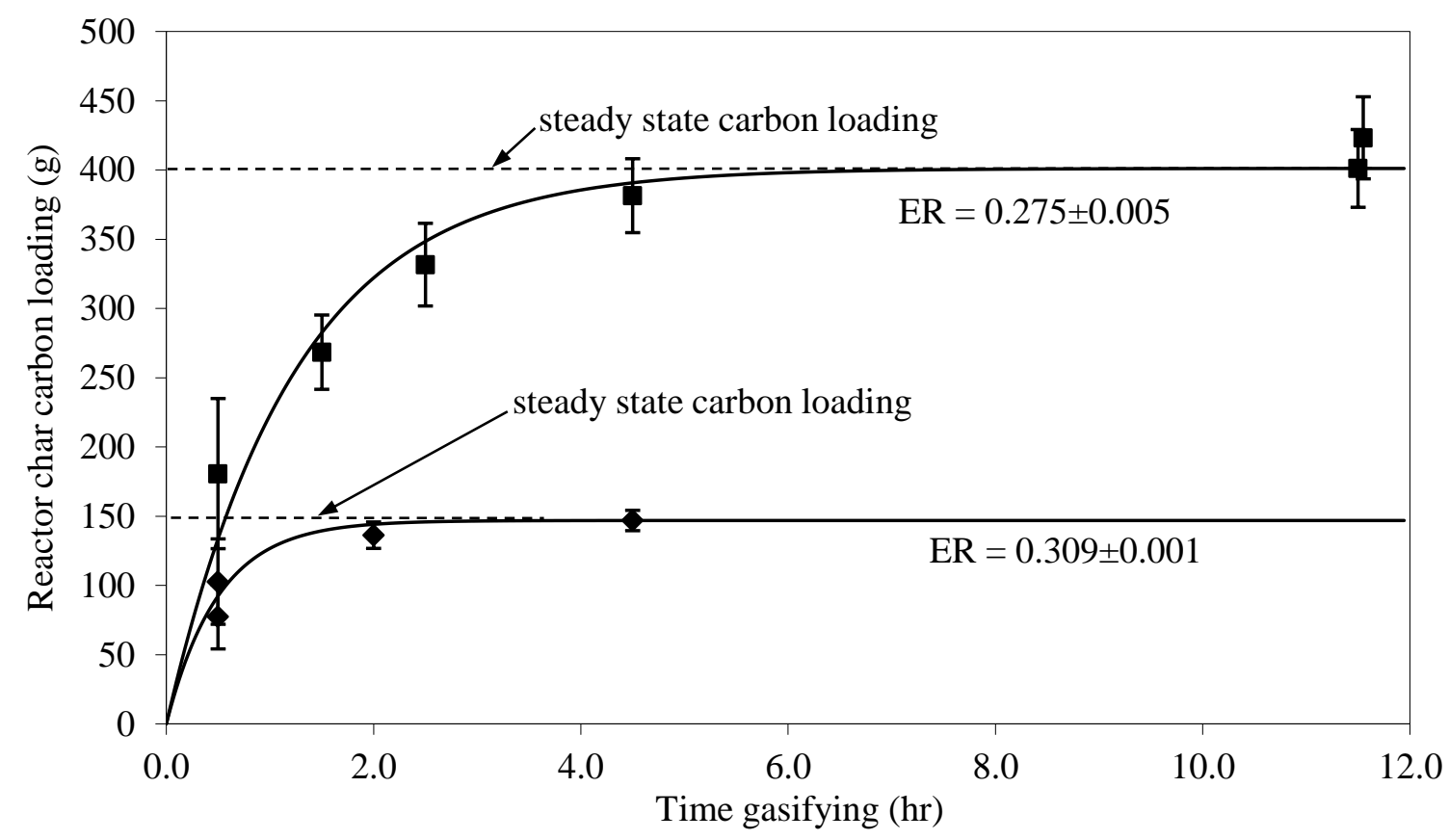

Figure 4. Comparison between experimental char carbon loadings in the reactor and model predictions at various times for gasification of fine ground seed corn at $715^{\circ} \mathrm{C}$ and two ER values (0.27 and 0.31). Data shown is for experiments $a-j$.

\subsubsection{Effect of the superficial gas velocity}

Superficial gas velocity was varied by changing the air supply rate and adjusting the biomass feed rate to achieve similar ER values across the experiments. Figure 5 plots $\mathrm{k}_{\mathrm{r}}$ and $\mathrm{k}_{\mathrm{e}}$ as functions of the superficial gas velocity, $\mathrm{U}_{\mathrm{fb}}$, in the reactor during gasification of ground seed corn at $750^{\circ} \mathrm{C}$ with an ER of 0.29 (Experiments $k, l, m$ ). The absence of much effect of superficial gas velocity on $\mathrm{k}_{\mathrm{r}}$ demonstrated that gasification of ground seed corn at these conditions was not limited by mass transfer from the bulk fluid to the char particles, which is consistent with the findings of others [7], [24], [52]-[58]. The increasing trend of $k_{\mathrm{e}}$ with increasing superficial gas velocities shown in Figure 5 was expected as larger particles became elutriable and physical attrition increased [47], [59].

Increasing superficial gas velocity increased char elutriation rates but did not increase chemical reaction rates beyond the uncertainty in the data, resulting in a decrease in both $Y_{t c}$ (Eq. (9)) and $Y_{c c}$ (Eq. (12)), as shown in Figure 6. Conversely, gas carbon yield increased as superficial gas velocity was 
reduced. In other words, increasing the diameter of the gasifier for a given biomass feed rate should achieve low char elutriation rates and correspondingly higher gas carbon yields.

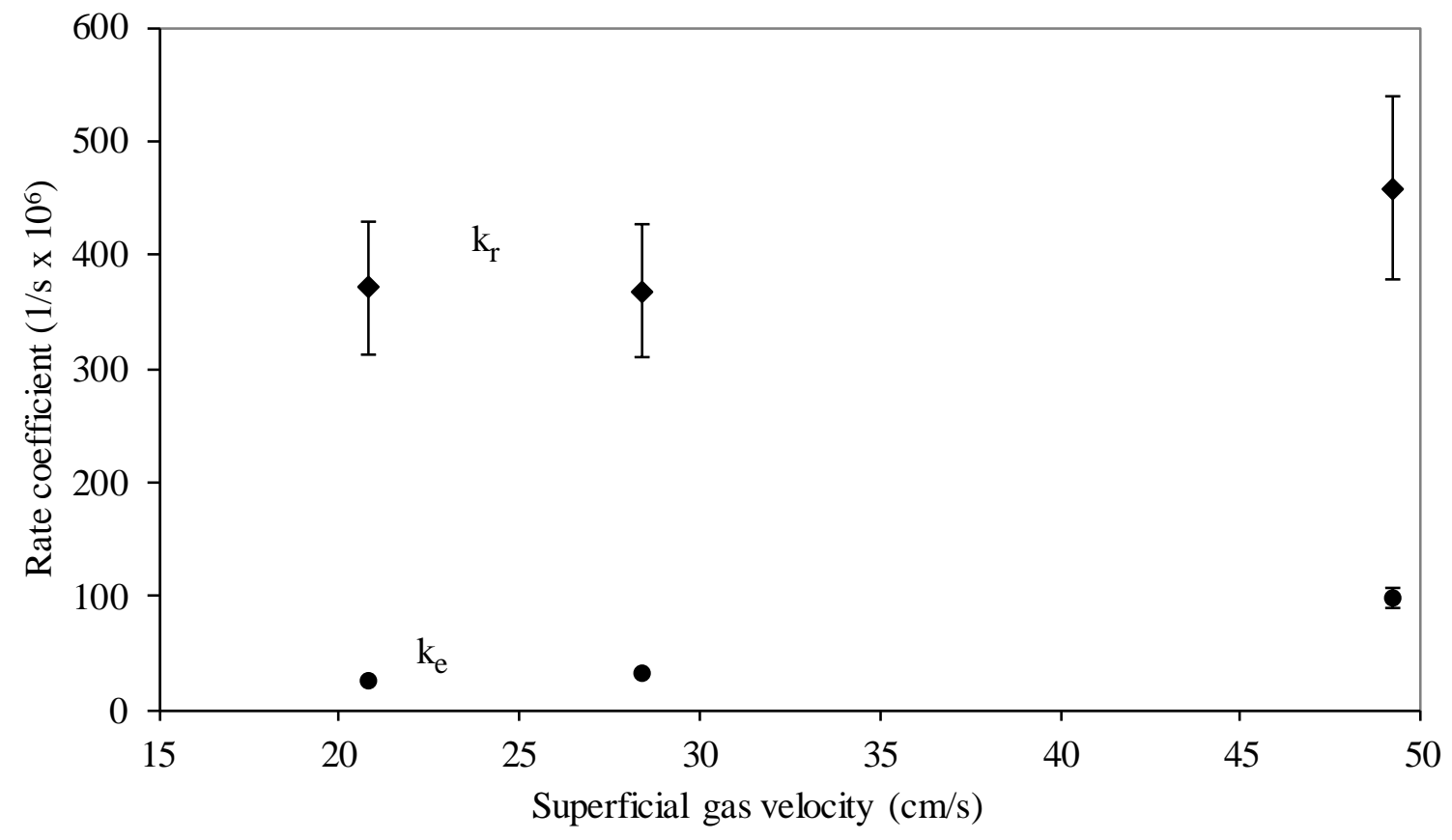

Figure 5. Rate coefficient for char carbon conversion and elutriation as a function of the superficial gas velocity during gasification of fine ground seed corn at approximately $750^{\circ} \mathrm{C}$ and an ER of 0.29 . Data from experiments $k, l$, and $m$.

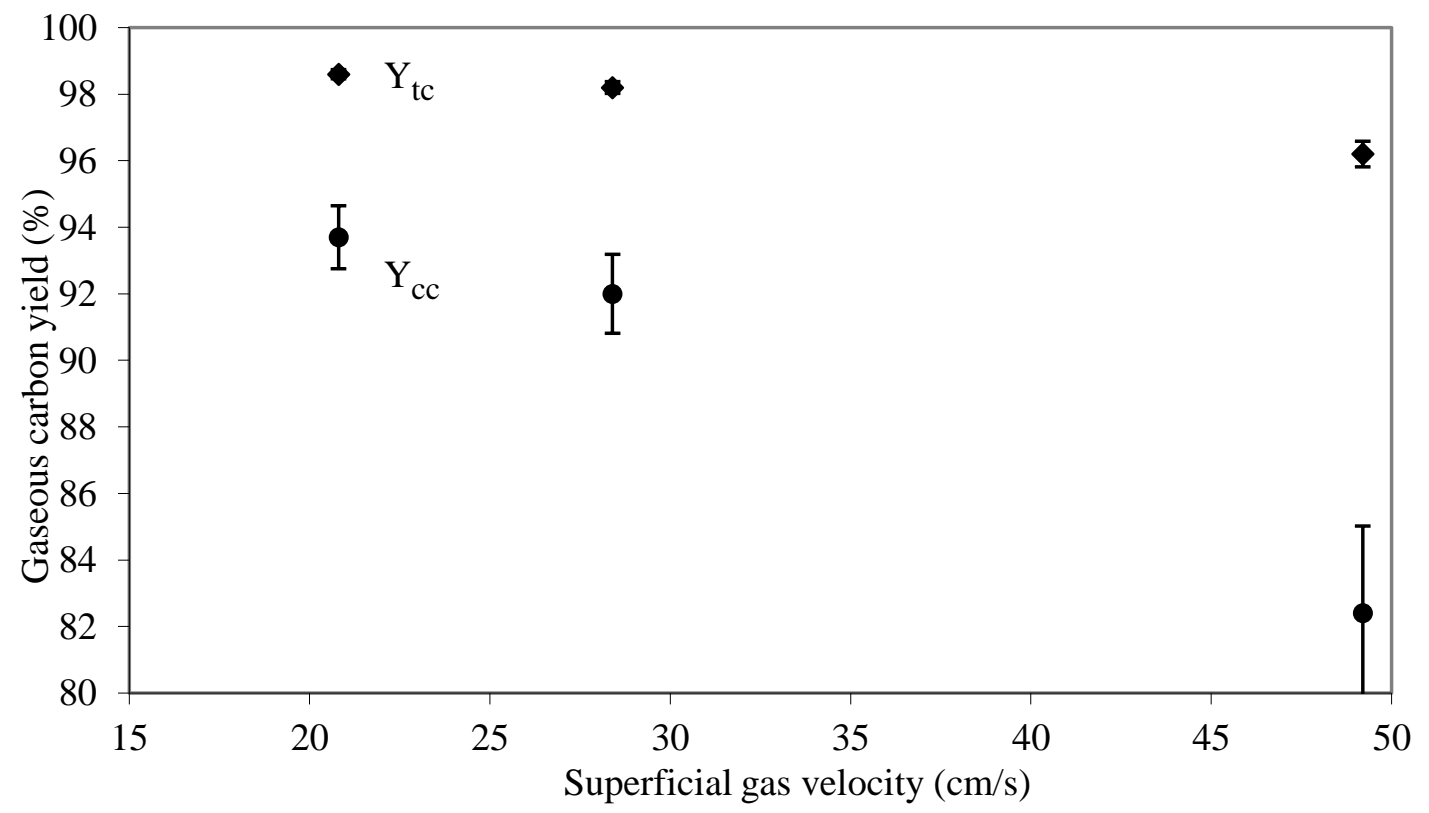

Figure 6. Total carbon gas yield from biomass and carbon gas yield from char carbon as a function of superficial gas velocity during gasification of fine ground seed corn at approximately $750^{\circ} \mathrm{C}$ and an ER of 0.29. Data from experiments $k, l$, and $m$. 


\subsubsection{Effect of equivalence ratio}

Rate coefficients for chemical reaction and elutriation during gasification of ground seed corn at $750^{\circ} \mathrm{C}$ and $800^{\circ} \mathrm{C}$ are plotted as functions of equivalence ratio in Figure 7 (Experiments $\mathrm{n}-\mathrm{t}$ ). ER values were varied by altering the biomass feed rate while maintaining a constant air flow rate of 50 slpm. Linear regression lines were added to the figure for clarity. Both temperatures show $\mathrm{k}_{\mathrm{r}}$ increasing linearly with increased ER as a result of increased char oxidation.

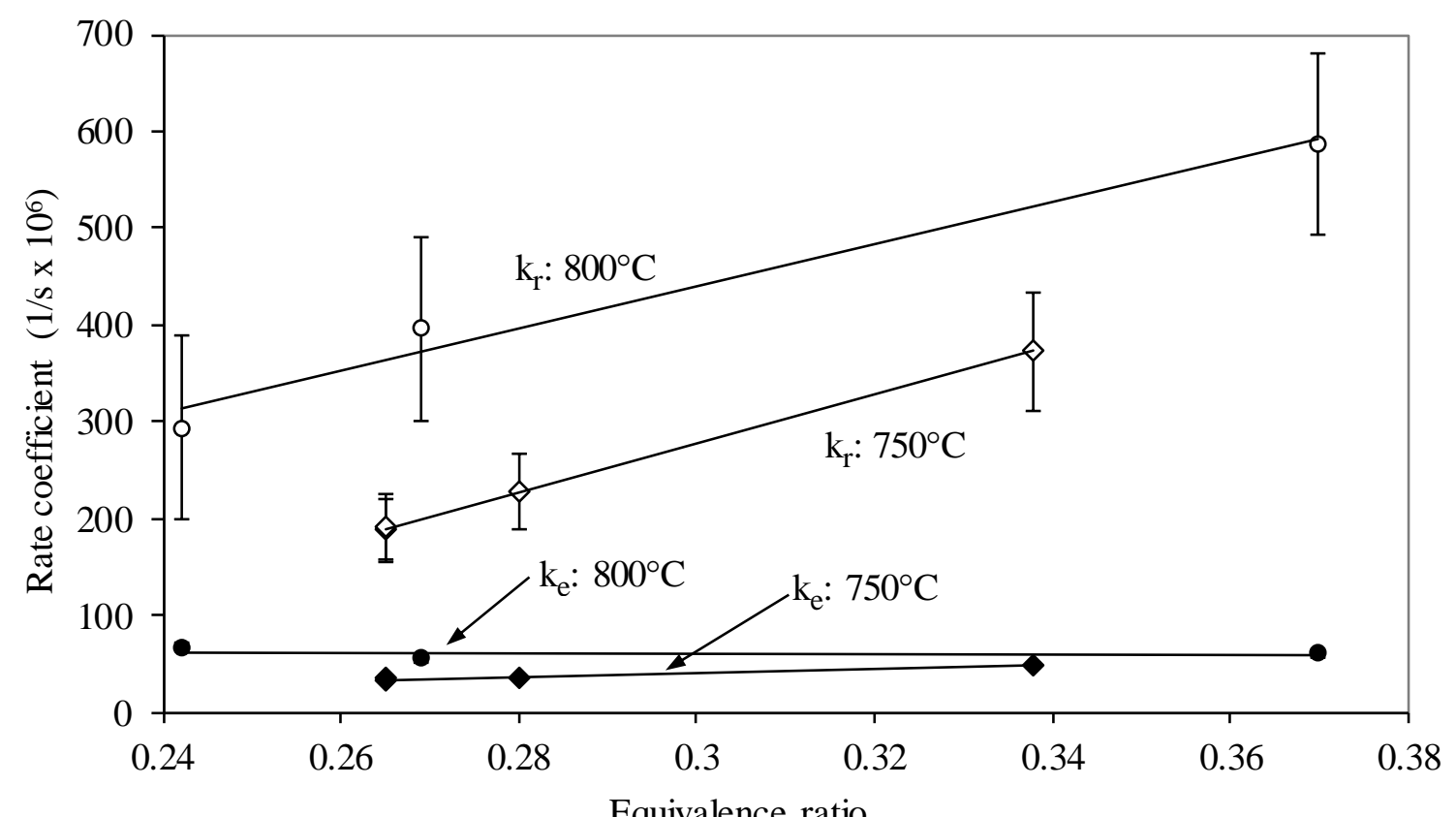

Figure 7. Rate coefficient for char carbon conversion and elutriation as a function of ER for gasification of fine ground seed corn at approximately $750^{\circ} \mathrm{C}$ and $800^{\circ} \mathrm{C}$. Data from experiments $n-t$.

During these tests superficial gas velocity in the gasifier decreased as equivalence ratio was increased. This was result of the corresponding lower biomass feed rates generating smaller volumes of volatile gases and vapors. Elutriation rate coefficient was expected to decrease with reductions in the superficial gas velocity in accordance with the trend demonstrated in Figure 5. However, despite a 10-20\% decrease in superficial gas velocity with increased ER, elutriation rate coefficients plotted in Figure 7 are constant or increase only slightly. Increasing elutriation rates with increasing ER despite decreasing superficial gas velocity indicates the presence of increasing rates of chemically enhanced attrition. Chemically enhanced attrition is a form of percolation in which chemical conversion weakens the char particles 
making them more susceptible to physical attrition. Scala et al. [60], [61] observed this phenomena during combustion of black locust char.

Steam and $\mathrm{CO}_{2}$ gasification reactions are endothermic and are therefore expected to increase with temperature. Figure 7 is consistent with this expectation showing larger $\mathrm{k}_{\mathrm{r}}$ values at $800^{\circ} \mathrm{C}$ compared to $750^{\circ} \mathrm{C}$ regardless of ER.

Figure 7 also shows a larger elutriation rate coefficient for gasification at $800^{\circ} \mathrm{C}$ than at $750^{\circ} \mathrm{C}$, consistent with increased chemically enhanced attrition due to the increased chemical conversion experienced at higher temperatures. However, the data are not conclusive in this case as the increased elutriation may be the result of higher superficial gas velocity due to increased volatiles release as temperature increases.

Gas carbon yield from char, $\mathrm{Y}_{\mathrm{cc}}$ (Eq. (12)), and total gas carbon yield from biomass, $\mathrm{Y}_{\mathrm{tc}}$ (Eq. (9)), are plotted as functions of ER in Figure 8. As expected, increased carbon gas yield from char and total carbon gas yield were realized with increased equivalence ratio for both gasification temperatures.

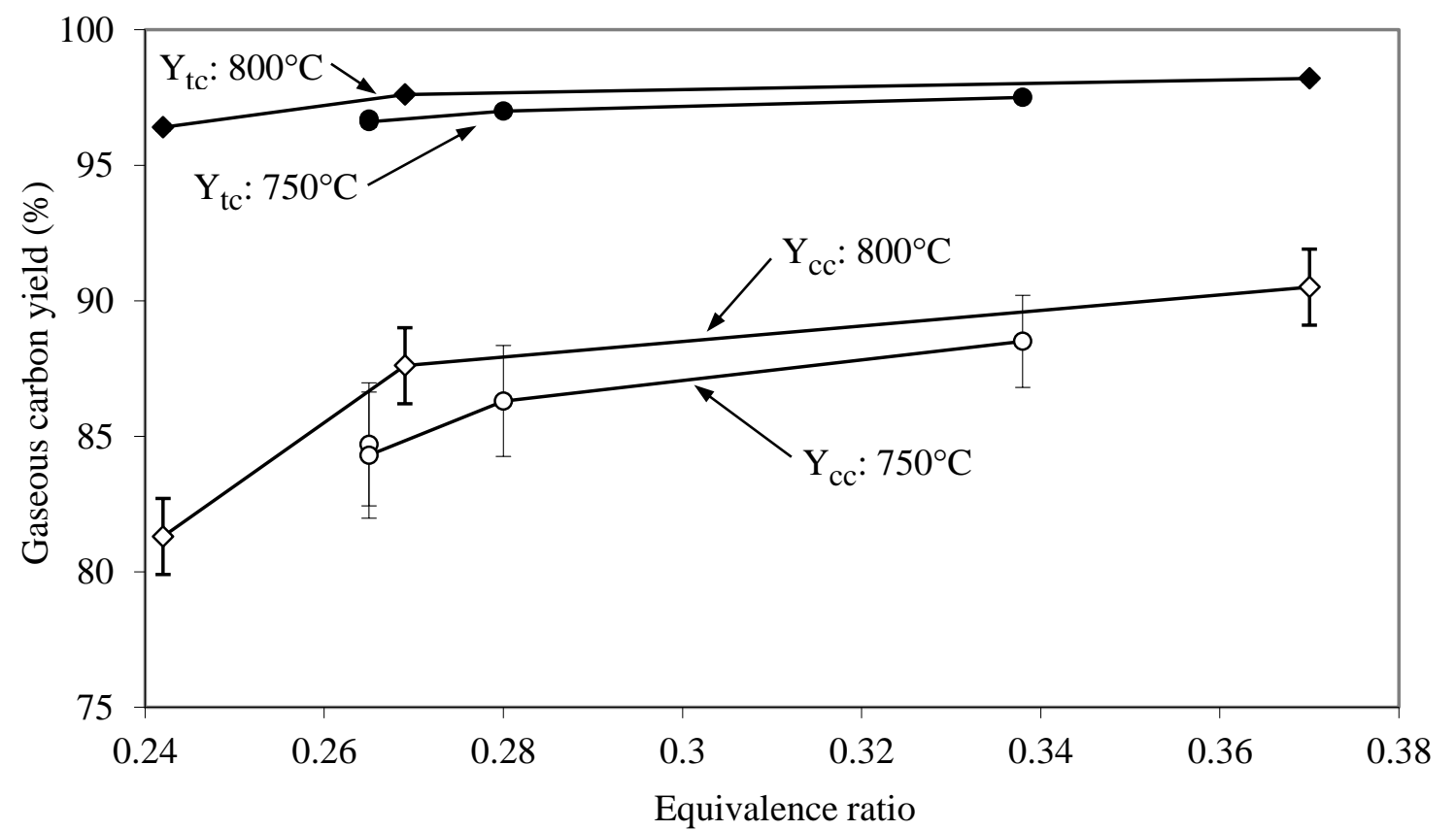

Figure 8. Total carbon gas yield $\left(\mathrm{Y}_{\mathrm{tc}}\right)$ from biomass and carbon gas yield $\left(\mathrm{Y}_{\mathrm{cc}}\right)$ from char carbon as a function of ER for gasification of fine ground seed corn at approximately $750^{\circ} \mathrm{C}$ and $800^{\circ} \mathrm{C}$. Data from experiments $n-t$ ) 
Consistent with published data for various types of biomass [1], [9], [11]-[15], [21], [23], [26], the results of this study show increased carbon gas yield with increased equivalence ratios. Carbon balance analysis revealed chemical reaction rates increased linearly with increased ER over the ranges tested. The analysis also showed steady or slightly increasing elutriation rates with increased ER in spite of decreasing reactor gas velocities. This suggests that chemically enhanced attrition may have been active during gasification of ground seed corn, limiting the yield of carbon bearing gases.

\subsubsection{Effect of temperature}

Figure 9 plots $\mathrm{k}_{\mathrm{r}}$ and $\mathrm{k}_{\mathrm{e}}$ as a function of temperature for the gasification of ground seed corn (Experiments $j, o, q, r$ ). The figure shows a large increase in the chemical reaction rate coefficient with temperature as well as an increase in the elutriation rate coefficient. Whether this increase in elutriation was caused by increased chemically enhanced attrition, increased fragmentation during devolatilization due to the higher temperature [26], [62], [63], increased superficial gas velocity arising from higher temperatures, or some combination of these factors, was not discernable from this data.

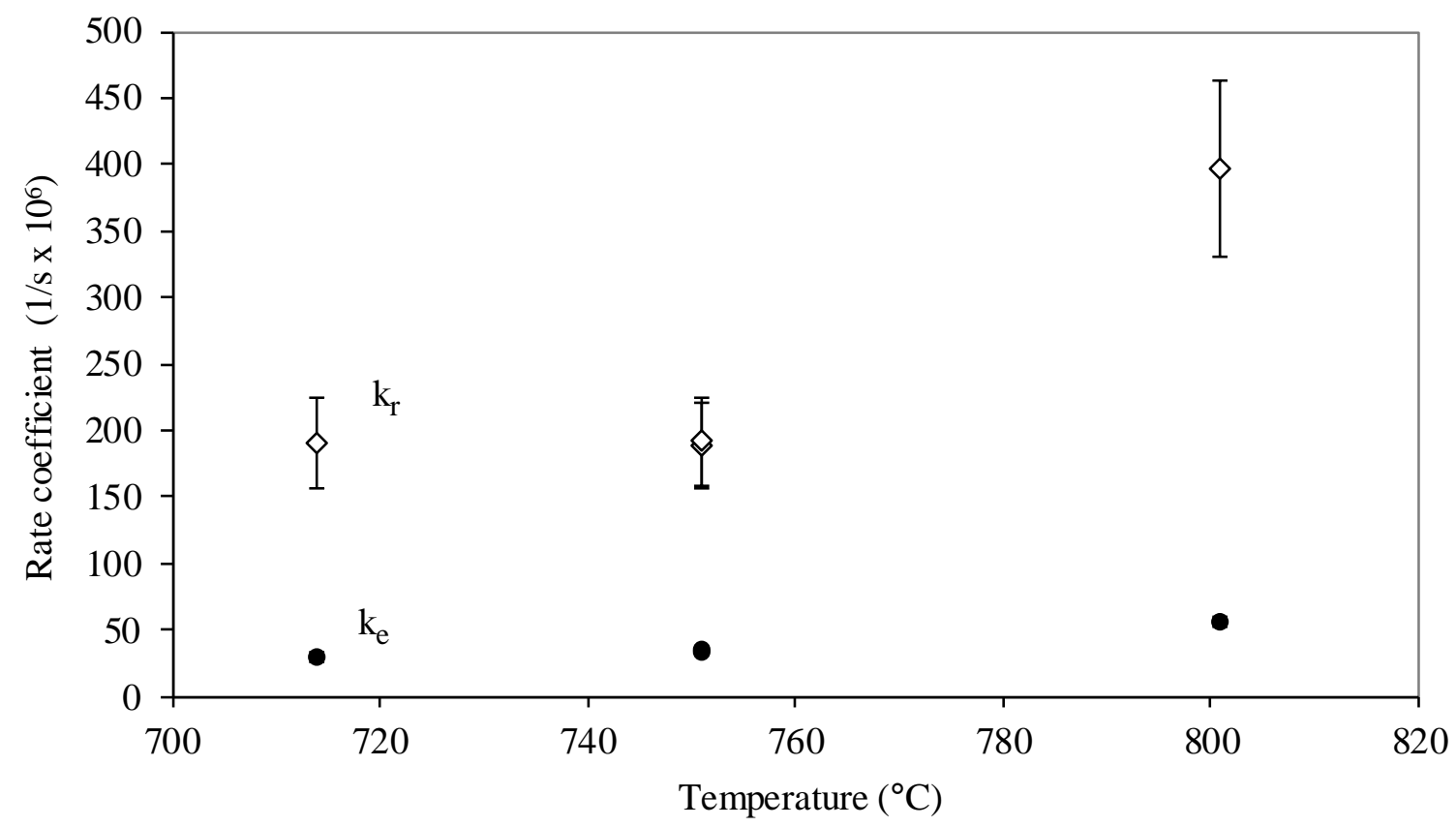

Figure 9. Rate coefficient for char carbon conversion and elutriation as functions of temperature for the gasification of fine ground seed corn at an average ER of 0.27. Data from experiments $j, o, q, r$. 
Figure 10 plots carbon gas yield as a function of gasification temperature. Within the uncertainties of the data the figure shows little or no change in $\mathrm{Y}_{\mathrm{cc}}$ across the entire temperature range and only a modest increase in $\mathrm{Y}_{\mathrm{tc}}$ due in part to the additional volatile release experienced at the higher temperatures [32], [34], [41]-[45], [51]. Therefore, despite the fact that the chemical conversion per unit mass of char carbon doubles over the range of temperature tested, a near doubling of the elutriation rate prevented a significant increase in the carbon gas yield. The lack of improved carbon gas yield with increased temperature shown in this study is a trend that has been observed by others but not completely explained [1], [13], [14], [16], [17], [19], [20]. In this study the benefit of increased chemical reaction rates due to higher temperatures was offset by increased elutriation of carbon. Although other potential mechanisms cannot be ruled out based on the data, this result is consistent with the explanation that carbon gas yield was not limited by either mass transport or chemical kinetics but by chemically enhanced attrition of the char, which increased with temperature and the corresponding increased chemical reaction rates.

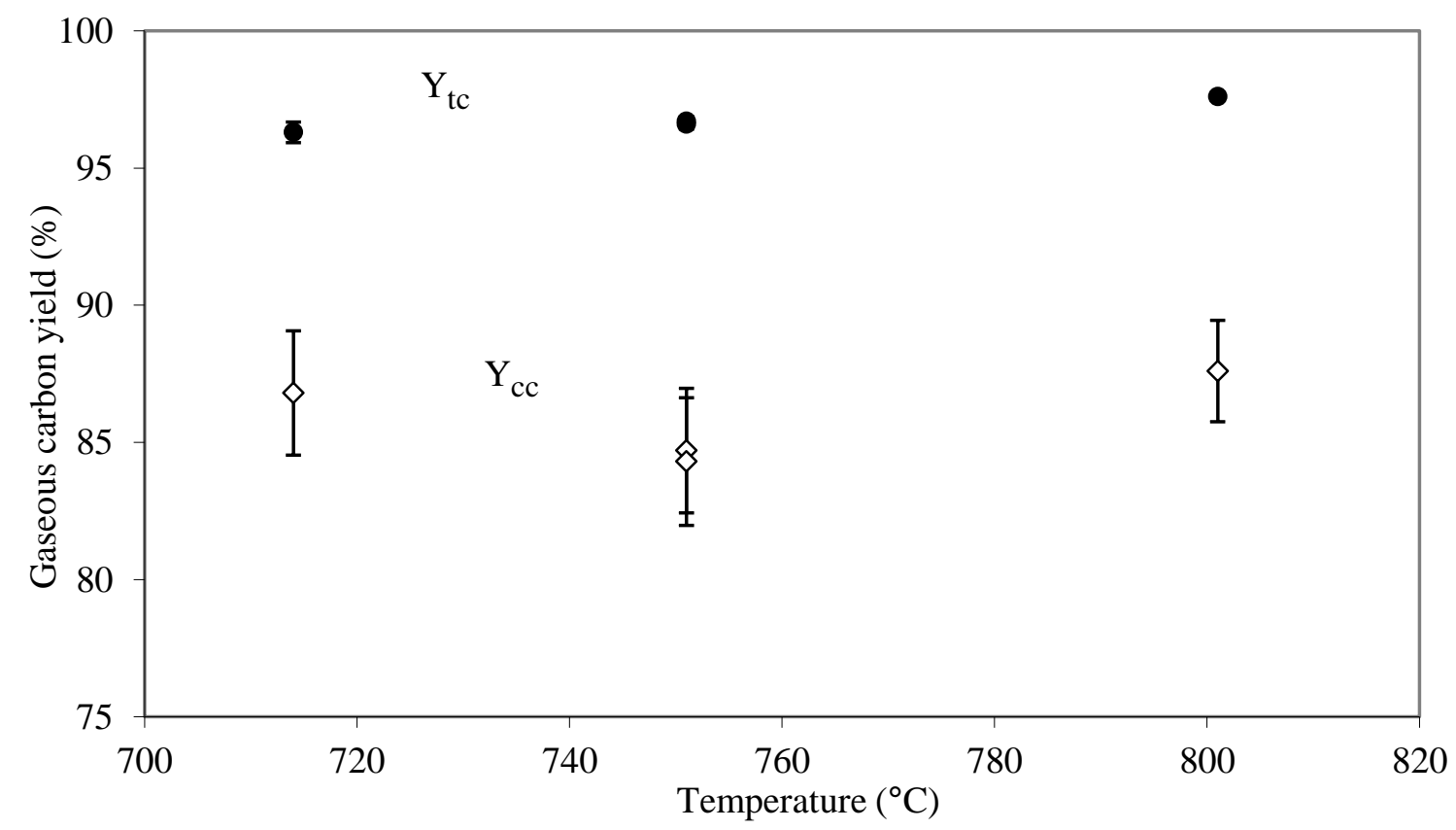

Figure 10. Total carbon gas yield from biomass and carbon gas yield from char carbon as functions of temperature for gasification of fine ground seed corn at an average ER of 0.27. Data from experiments $j$, $o, q, r$. 


\subsubsection{Effect of biomass particle size}

The gasification behavior of fine and coarse seed corn particles was compared. Based on sieve data the average mass weighted diameter was $0.96 \mathrm{~mm}$ for the fine ground seed corn and $1.9 \mathrm{~mm}$ for the coarse. Table 3 summarizes the results for gasification experiments at $750^{\circ} \mathrm{C}, \mathrm{ER}=0.28$ and $800^{\circ} \mathrm{C}, \mathrm{ER}$ $=0.27$ (Experiments $o, s, u, v)$. For each temperature the data show increased elutriation rates for coarse particles compared to fine particles while chemical reaction rates were similar. As the size of biomass particles increases the likelihood of fragmentation during devolatilization also increases [62], [63]. The increase in char surface area realized from increased fragmentation did not lead to an increase in chemical reaction rate coefficient because, as shown earlier (see Section 4.3.1), in these experiments reaction rates were not limited by mass transfer from the bulk fluid to the char particle. Additionally, it is likely that many of the fragments were of elutriable size and left the reactor after being formed with little time for chemical reaction, resulting in the increased elutriation rates for the coarse fuel particles shown in the table. Table 3 also shows a decrease in $Y_{c c}$ and $Y_{t c}$ as the particle size was increased, which is consistent with trends observed by Nikoo and Mahinpey [30]. The decrease in carbon gas yield observed here was expected given the higher elutriation rates and similar chemical reaction rates for coarse corn compared to the fine.

Table 3. Ground seed corn gasification data used to analyze the effect of biomass particle size

\begin{tabular}{|c|c|c|c|c|c|c|c|c|c|}
\hline Experiment & $\begin{array}{l}\text { Temp } \\
\left({ }^{\circ} \mathrm{C}\right)\end{array}$ & ER & $\begin{array}{l}\mathrm{n}_{\mathrm{H} 2 \mathrm{O}} / \mathrm{n}_{\mathrm{cc}} \\
(\mathrm{mol} / \mathrm{mol})\end{array}$ & $\begin{array}{c}\mathrm{U}_{\mathrm{fb}} \\
(\mathrm{cm} / \mathrm{s})\end{array}$ & $\begin{array}{c}\text { Biomass } \\
\text { Size }\end{array}$ & $\begin{array}{c}\mathrm{k}_{\mathrm{r}} \\
\left(\mathrm{x} 10^{6} \mathrm{~s}^{-1}\right)\end{array}$ & $\begin{array}{c}\mathrm{k}_{\mathrm{e}} \\
\left(\mathrm{x} 10^{6} \mathrm{~s}^{-1}\right)\end{array}$ & $\begin{array}{l}\mathrm{Y}_{\mathrm{cc}} \\
(\%)\end{array}$ & $\begin{array}{l}\mathrm{Y}_{\mathrm{tc}} \\
(\%)\end{array}$ \\
\hline $\bar{s}$ & 753 & 0.28 & $0.9 \pm 0.15$ & $30 \pm 1$ & Fine & $230 \pm 40$ & $36 \pm 2$ & $86 \pm 2$ & $97.0 \pm 0.2$ \\
\hline$u$ & 746 & 0.28 & $0.9 \pm 0.15$ & $26 \pm 1$ & Coarse & $210 \pm 40$ & $46 \pm 3$ & $82 \pm 3$ & $95.9 \pm 0.2$ \\
\hline$o$ & 801 & 0.27 & $1.0 \pm 0.15$ & $35 \pm 1$ & Fine & $400 \pm 70$ & $56 \pm 4$ & $88 \pm 2$ & $97.6 \pm 0.1$ \\
\hline$v$ & 801 & 0.27 & $1.0 \pm 0.15$ & $34 \pm 1$ & Coarse & $350 \pm 70$ & $97 \pm 6$ & $78 \pm 4$ & $95.8 \pm 0.2$ \\
\hline
\end{tabular}

\subsubsection{Effect of $\mathrm{H}_{2} \mathrm{O}$ concentration}

Moisture in the ground seed corn provided a molar ratio of water vapor to char carbon $\left(\mathrm{n}_{\mathrm{H} 2 \mathrm{O}} / \mathrm{n}_{\mathrm{cc}}\right)$ of 1.0 during gasification at $800^{\circ} \mathrm{C}$. This ratio was increased by injecting wet steam into the bottom of the fluidized bed to achieve $\mathrm{n}_{\mathrm{H} 2 \mathrm{O}} / \mathrm{n}_{\mathrm{cc}}$ as high as 2.9. 
Figure 11 shows a significant increase in $\mathrm{k}_{\mathrm{r}}$ and $\mathrm{k}_{\mathrm{e}}$ as $\mathrm{n}_{\mathrm{H} 2 \mathrm{O}} / \mathrm{n}_{\mathrm{cc}}$ increased (Experiments $n, w, x$ ). Similar to the result observed for temperature (see Section 4.3.3), increased chemical reaction rates corresponded to increased elutriation rates, indicating the presence of chemically enhanced attrition. When chemically enhanced attrition is operative, increased chemical reaction is offset by increased char elutriation leaving carbon gas yields essentially unchanged as shown in Figure 12. The figure shows a slight increase in $Y_{t c}$ and no significant change in $Y_{c c}$ beyond uncertainty in the data as $n_{H 20} / n_{c c}$ increased from 1.0 to nearly 3.0. Thus, while the addition of $\mathrm{H}_{2} \mathrm{O}$ may be desirable for reforming tar or to increase $\mathrm{H}_{2}$ concentrations via the water-gas shift reaction [16], [20], [21], [31], [43], [64], it did not improve the yield of carbon bearing gases in these experiments.

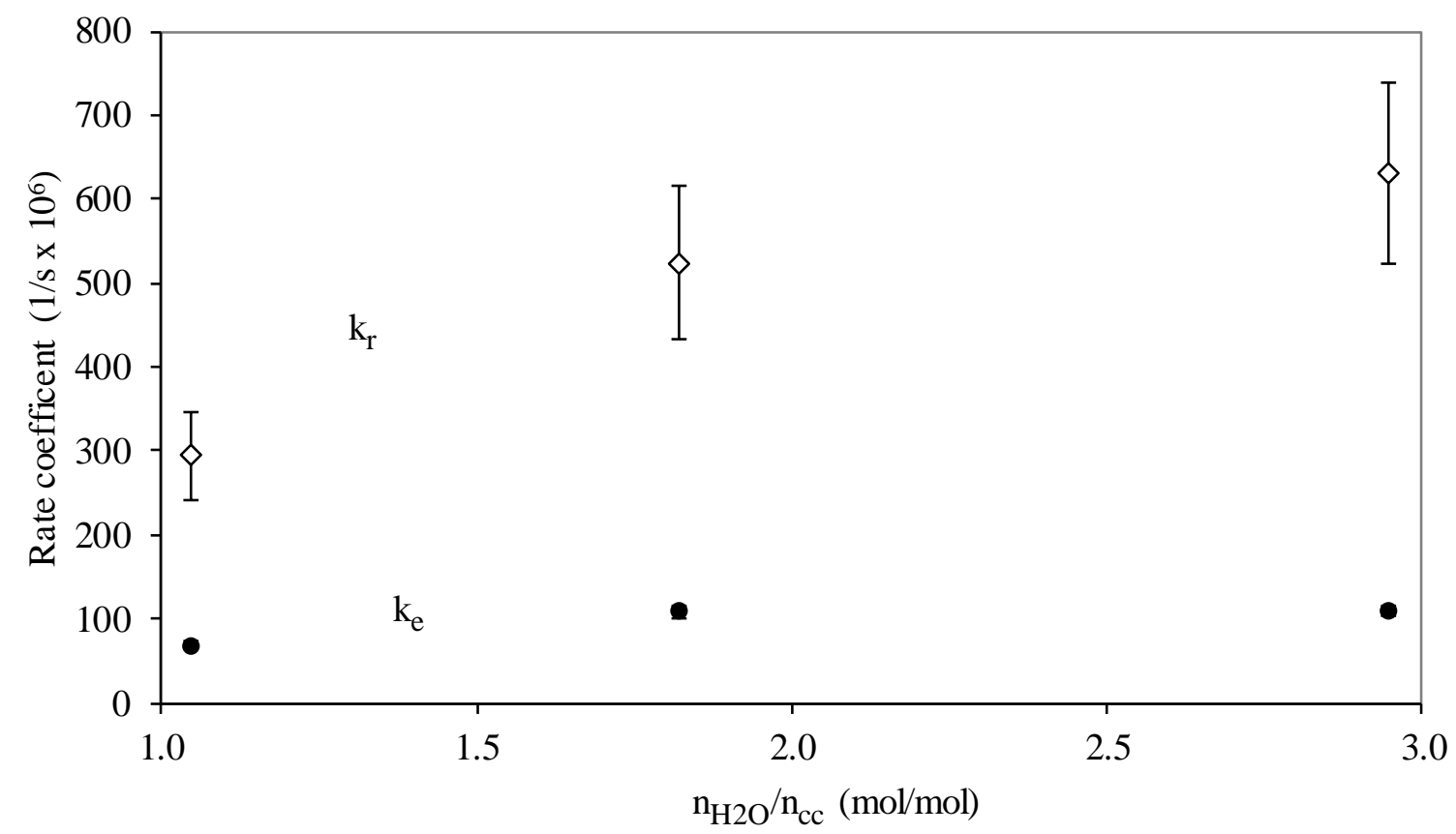

Figure 11. Rate coefficient for char carbon conversion and elutriation as functions of the water vapor concentration per mole of char carbon entering the reactor during gasification of fine ground seed corn at approximately $800^{\circ} \mathrm{C}, \mathrm{ER}=0.25$. Data from experiments $n, w, x$. 


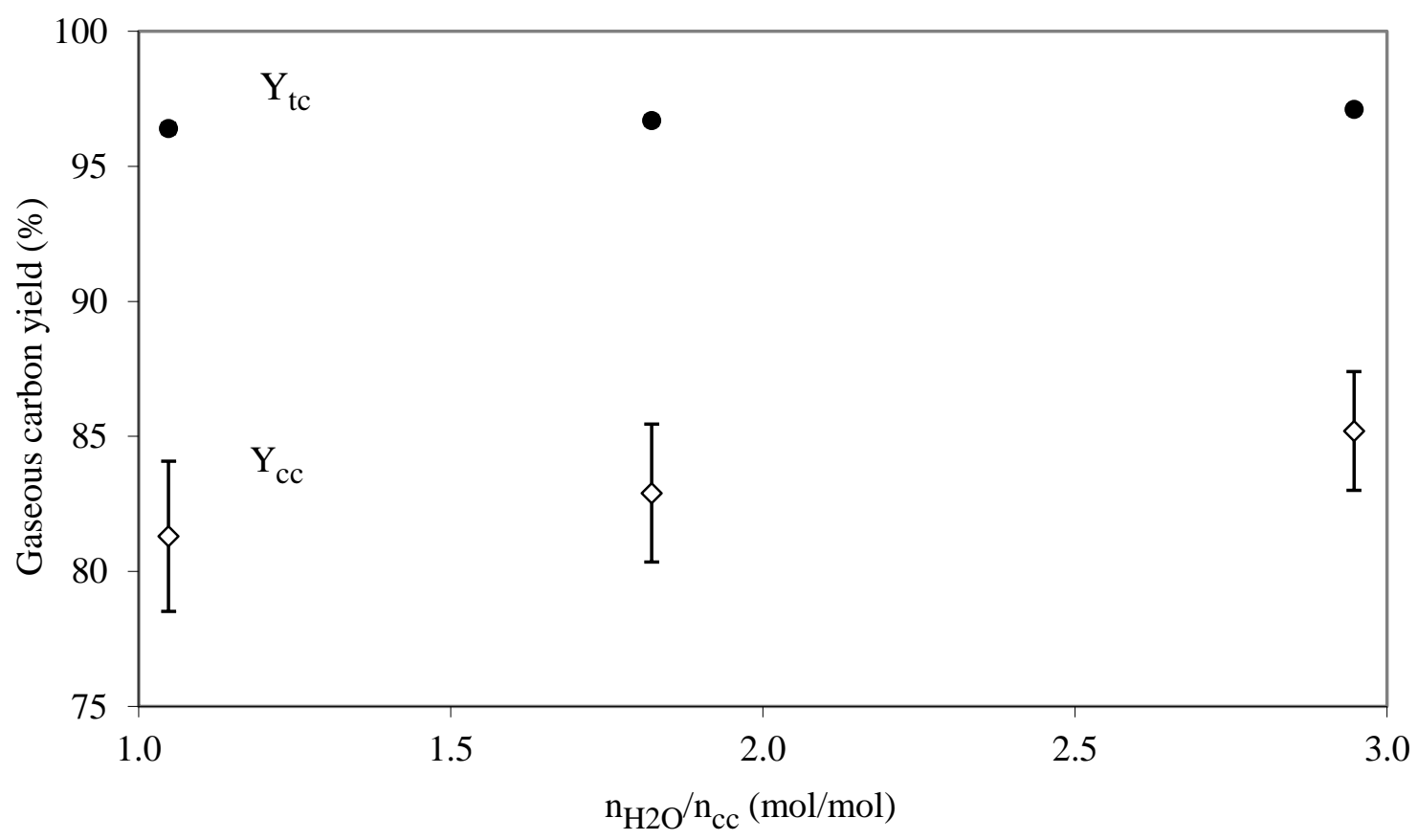

Figure 12. Total carbon gas yield from biomass and carbon gas yield from char carbon as a function of the water vapor concentration per mole of char carbon entering the reactor during gasification of fine ground seed corn at approximately $800^{\circ} \mathrm{C}, \mathrm{ER}=0.25$. Data from experiments $n, w, x$.

\section{Conclusions}

A char carbon balance on a fluidized bed gasifier was used to better understand the conversion of char carbon to carbon bearing gases. In experiments with ground seed corn, it was found that the yield of carbon bearing gases was often limited by chemically enhanced attrition of the char particles. Therefore, efforts to improve carbon gas yield by increasing chemical reaction rates are frustrated by increased elutriation rates from chemically enhanced attrition. These results explain why previous studies found little improvement in carbon gas yield when operating under conditions that increased the rate of solidgas reactions of char. The most promising strategy to improve yields of carbon-bearing gases during fluidized bed gasification of biomass is to reduce superficial gas velocity, which decreases char attrition while maintaining the rate of gas-solid reactions. 


\section{Acknowledgements}

This work was supported by the Natural Resources Conservation Service, U. S. Department of Agriculture under Agreement No. NRCS 68-3-475-3151; the U. S. Department of Energy under Agreement No. DE-FC36-01G011091; and the ISU Foundation under the Bergles Professorship in Thermal Sciences at Iowa State University. Any opinions, findings, conclusions, or recommendations expressed herein are those of the authors and do not necessarily reflect the views of the sponsors.

\section{References}

[1] X. T. Li, J. R. Grace, C. J. Lim, A. P. Watkinson, H. P. Chen, and J. R. Kim, "Biomass gasification in a circulating fluidized bed," Biomass Bioenergy, vol. 26, no. 2, pp. 171-193, 2004.

[2] C. M. Kinoshita, Y. Wang, and P. K. Takahashi, "Chemical equilibrium computations for gasification of biomass to produce methanol," Energy Sources, vol. 13, no. 3, pp. 361-368, 1991.

[3] X. Li, J. R. Grace, A. P. Watkinson, C. J. Lim, and A. Ergüdenler, "Equilibrium modeling of gasification: a free energy minimization approach and its application to a circulating fluidized bed coal gasifier," Fuel, vol. 80, no. 2, pp. 195-207, 2001.

[4] M. J. Prins, K. J. Ptasinski, and F. Janssen, "Thermodynamics of gas-char reactions: first and second law analysis," Chem. Eng. Sci., vol. 58, no. 3, pp. 1003-1011, 2003.

[5] M. Ruggiero and G. Manfrida, "An equilibrium model for biomass gasification processes," Renew. Energy, vol. 16, no. 1-4, pp. 1106-1109, 1999.

[6] G. Schuster, G. Löffler, K. Weigl, and H. Hofbauer, "Biomass steam gasification-an extensive parametric modeling study," Bioresour. Technol., vol. 77, no. 1, pp. 71-79, 2001.

[7] T. B. Reed editor, Biomass Gasification: Principles and Technology, Solar Energy Research Institute, Noyes Data Corp., Park Ridge, N.J., 1981.

[8] M. Baratieri, P. Baggio, L. Fiori, and M. Grigiante, "Biomass as an energy source: Thermodynamic constraints on the performance of the conversion process," Bioresour. Technol., vol. 99, no. 15, pp. 7063-7073, Oct. 2008.

[9] L. Zeng and A. R. Van Heiningen, "Carbon gasification of kraft black liquor solids in the presence of TiO2 in a fluidized bed," Energy Fuels, vol. 14, no. 1, pp. 83-88, 2000.

[10] P. Garcia-Ibanez, A. Cabanillas, and J. M. Sánchez, "Gasification of leached orujillo (olive oil waste) in a pilot plant circulating fluidised bed reactor. Preliminary results," Biomass Bioenergy, vol. 27, no. 2, pp. 183-194, 2004.

[11] A. Gómez-Barea, R. Arjona, and P. Ollero, "Pilot-plant gasification of olive stone: a technical assessment," Energy Fuels, vol. 19, no. 2, pp. 598-605, 2005.

[12] S. R. Kersten, W. Prins, A. Van der Drift, and W. P. M. van Swaaij, "Experimental fact-finding in CFB biomass gasification for ECN's 500 kWth pilot plant," Ind. Eng. Chem. Res., vol. 42, no. 26, pp. 6755-6764, 2003.

[13] P. M. Lv, Z. H. Xiong, J. Chang, C. Z. Wu, Y. Chen, and J. X. Zhu, "An experimental study on biomass air-steam gasification in a fluidized bed," Bioresour. Technol., vol. 95, no. 1, pp. 95-101, 2004.

[14] F. Miccio, O. Moersch, H. Spliethoff, and K. R. G. Hein, "Generation and conversion of carbonaceous fine particles during bubbling fluidised bed gasification of a biomass fuel," Fuel, vol. 78, no. 12, pp. 1473-1481, 1999.

[15] A. van der Drift and J. van Doorn, "Effect of fuel size and process temperature on fuel gas quality from CFB gasification of biomass," Prog. Thermochem. Biomass Convers., p. 265, 2008. 
[16] J. Herguido, J. Corella, and J. Gonzalez-Saiz, "Steam gasification of lignocellulosic residues in a fluidized bed at a small pilot scale. Effect of the type of feedstock," Ind. Eng. Chem. Res., vol. 31, no. 5, pp. 1274-1282, 1992.

[17] A. van der Drift, J. van Doorn, and J. W. Vermeulen, "Ten residual biomass fuels for circulating fluidized-bed gasification,” Biomass Bioenergy, vol. 20, no. 1, pp. 45-56, 2001.

[18] A. van der Drift and C. M. van der Meijden, "Ways to increase the carbon conversion of a CFB gasifier," in 12th European Conference and Exhibition on Biomass for Energy and Climate Protection, Amsterdam, 2002, p. 48.

[19] C. Franco, F. Pinto, I. Gulyurtlu, and I. Cabrita, "The study of reactions influencing the biomass steam gasification process," Fuel, vol. 82, no. 7, pp. 835-842, 2003.

[20] J. Gil, M. P. Aznar, M. A. Caballero, E. Francés, and J. Corella, "Biomass gasification in fluidized bed at pilot scale with steam-oxygen mixtures. Product distribution for very different operating conditions," Energy Fuels, vol. 11, no. 6, pp. 1109-1118, 1997.

[21] M. Campoy, A. Gómez-Barea, A. L. Villanueva, and P. Ollero, "Air-Steam Gasification of Biomass in a Fluidized Bed under Simulated Autothermal and Adiabatic Conditions," Ind. Eng. Chem. Res., vol. 47, no. 16, pp. 5957-5965, Aug. 2008.

[22] J. Kramb, J. Konttinen, A. Gómez-Barea, A. Moilanen, and K. Umeki, "Modeling biomass char gasification kinetics for improving prediction of carbon conversion in a fluidized bed gasifier," Fuel, vol. 132, pp. 107-115, Sep. 2014.

[23] A. Kumar, K. Eskridge, D. D. Jones, and M. A. Hanna, "Steam-air fluidized bed gasification of distillers grains: Effects of steam to biomass ratio, equivalence ratio and gasification temperature," Bioresour. Technol., vol. 100, no. 6, pp. 2062-2068, Mar. 2009.

[24] M. Campoy, A. Gómez-Barea, F. B. Vidal, and P. Ollero, "Air-steam gasification of biomass in a fluidised bed: Process optimisation by enriched air," Fuel Process. Technol., vol. 90, no. 5, pp. 677685, May 2009.

[25] A. Gómez-Barea, B. Leckner, A. Villanueva Perales, S. Nilsson, and D. Fuentes Cano, "Improving the performance of fluidized bed biomass/waste gasifiers for distributed electricity: A new threestage gasification system," Appl. Therm. Eng., vol. 50, no. 2, pp. 1453-1462, Feb. 2013.

[26] A. Gómez-Barea and B. Leckner, "Estimation of gas composition and char conversion in a fluidized bed biomass gasifier," Fuel, vol. 107, pp. 419-431, May 2013.

[27] A. Gómez-Barea, P. Ollero, and B. Leckner, "Optimization of char and tar conversion in fluidized bed biomass gasifiers," Fuel, vol. 103, pp. 42-52, Jan. 2013.

[28] S. Kaewluan and S. Pipatmanomai, "Potential of synthesis gas production from rubber wood chip gasification in a bubbling fluidised bed gasifier," Energy Convers. Manag., vol. 52, no. 1, pp. 7584, Jan. 2011.

[29] D. Neves, H. Thunman, A. Matos, L. Tarelho, and A. Gómez-Barea, "Characterization and prediction of biomass pyrolysis products," Prog. Energy Combust. Sci., vol. 37, no. 5, pp. 611-630, Sep. 2011.

[30] M. B. Nikoo and N. Mahinpey, "Simulation of biomass gasification in fluidized bed reactor using ASPEN PLUS," Biomass Bioenergy, vol. 32, no. 12, pp. 1245-1254, Dec. 2008.

[31] I. Narvaez, A. Orio, M. P. Aznar, and J. Corella, "Biomass gasification with air in an atmospheric bubbling fluidized bed. Effect of six operational variables on the quality of the produced raw gas," Ind. Eng. Chem. Res., vol. 35, no. 7, pp. 2110-2120, 1996.

[32] C. Hanping, L. Bin, Y. Haiping, Y. Guolai, and Z. Shihong, "Experimental Investigation of Biomass Gasification in a Fluidized Bed Reactor," Energy Fuels, vol. 22, no. 5, pp. 3493-3498, Sep. 2008.

[33] V. Sricharoenchaikul, W. J. Frederick, and P. Agrawal, "Carbon distribution in char residue from gasification of kraft black liquor,” Biomass Bioenergy, vol. 25, no. 2, pp. 209-220, 2003.

[34] D. S. Scott, J. Piskorz, M. A. Bergougnou, R. Graham, and R. P. Overend, "The role of temperature in the fast pyrolysis of cellulose and wood," Ind. Eng. Chem. Res., vol. 27, no. 1, pp. 8-15, 1988. 
[35] C. Sheng and J. L. T. Azevedo, "Modeling biomass devolatilization using the chemical percolation devolatilization model for the main components," Proc. Combust. Inst., vol. 29, no. 1, pp. 407-414, 2002.

[36] V. Cozzani, C. Nicolella, M. Rovatti, and L. Tognotti, "Modeling and experimental verification of physical and chemical processes during pyrolysis of a refuse-derived fuel," Ind. Eng. Chem. Res., vol. 35, no. 1, pp. 90-98, 1996.

[37] V. Sricharoenchaikul, A. L. Hicks, and W. J. Frederick, "Carbon and char residue yields from rapid pyrolysis of kraft black liquor," Bioresour. Technol., vol. 77, no. 2, pp. 131-138, 2001.

[38] X. Bingyan, W. Chuangzhi, L. Zhengfen, and others, "Kinetic study on biomass gasification (A 1991 ISES Solar World Congress honors paper)," Sol. Energy, vol. 49, no. 3, pp. 199-204, 1992.

[39] W. J. Frederick Jr and M. Hupa, "Combustion properties of kraft black liquors," USDOE Assistant Secretary for Energy Efficiency and Renewable Energy, Washington, DC (United States). Office of Industrial Technologies; Tampella Power, Tampere (Finland); Ministry of Trade and Industry, Helsinki (Finland). Energy Dept.; Oregon State Univ., Corvallis, OR (United States); Aabo Akademi, Turku (Finland), 1993.

[40] P. Mathieu and R. Dubuisson, "Performance analysis of a biomass gasifier," Energy Convers. Manag., vol. 43, no. 9, pp. 1291-1299, 2002.

[41] R. Zanzi, K. Sjöström, and E. Björnbom, "Rapid pyrolysis of agricultural residues at high temperature," Biomass Bioenergy, vol. 23, no. 5, pp. 357-366, 2002.

[42] S. Gaur and T. B. Reed, Thermal data for natural and synthetic fuels. Marcel Dekker New York, 1998.

[43] A. Gómez-Barea, B. Leckner, and P. Ollero, "Methods to improve the performance of fluidized bed biomass gasifiers," in 2nd European conference on polygeneration, Tarragona (Spain), 2011.

[44] D. Fuentes-Cano, A. Gómez-Barea, S. Nilsson, and P. Ollero, "The influence of temperature and steam on the yields of tar and light hydrocarbon compounds during devolatilization of dried sewage sludge in a fluidized bed," Fuel, vol. 108, pp. 341-350, Jun. 2013.

[45] A. Gomez-Barea, S. Nilsson, F. Vidal Barrero, and M. Campoy, "Devolatilization of wood and wastes in fluidized bed," Fuel Process. Technol., vol. 91, no. 11, pp. 1624-1633, Nov. 2010.

[46] R. C. Brown, J. Ahrens, and N. Christofides, "The contributions of attrition and fragmentation to char elutriation from fluidized beds," Combust. Flame, vol. 89, no. 1, pp. 95-102, 1992.

[47] D. Harrison, R. Clift, and J. F. Davidson, Fluidization, 2nd ed. London: Academic Press, 1985.

[48] S. Q. Turn, C. M. Kinoshita, D. M. Ishimura, and J. Zhou, "The fate of inorganic constituents of biomass in fluidized bed gasification," Fuel, vol. 77, no. 3, pp. 135-146, 1998.

[49] A. Olivares, M. P. Aznar, M. A. Caballero, J. Gil, E. Francés, and J. Corella, "Biomass gasification: produced gas upgrading by in-bed use of dolomite," Ind. Eng. Chem. Res., vol. 36, no. 12, pp. 5220-5226, 1997.

[50] H.W. Coleman, W. G. Steele, Experimentation, Validation, and Uncertainty Analysis for Engineers, 3rd Edition, New York: Wiley, 2009.

[51] R. Zanzi, K. Sjöström, and E. Björnbom, "Rapid high-temperature pyrolysis of biomass in a freefall reactor," Fuel, vol. 75, no. 5, pp. 545-550, 1996.

[52] R. Backman, W. J. Frederick, and M. Hupa, "Basic studies on black-liquor pyrolysis and char gasification," Bioresour. Technol., vol. 46, no. 1-2, pp. 153-158, 1993.

[53] U. B. Desideri N. . and D. Fiaschi, "A biomass combustion-gasification model: validation and sensitivity analysis,” J. Energy Resour. Technol., vol. 117, p. 329, 1995.

[54] P. Ollero, A. Serrera, R. Arjona, and S. Alcantarilla, "The CO2 gasification kinetics of olive residue," Biomass Bioenergy, vol. 24, no. 2, pp. 151-161, 2003.

[55] R. H. Hurt, "Structure, properties, and reactivity of solid fuels," in Symposium (International) on Combustion, 1998, vol. 27, pp. 2887-2904.

[56] W. Klose and M. Wölki, "On the intrinsic reaction rate of biomass char gasification with carbon dioxide and steam," Fuel, vol. 84, no. 7, pp. 885-892, 2005. 
[57] E. Henrich, S. Bürkle, Z. I. Meza-Renken, and S. Rumpel, "Combustion and gasification kinetics of pyrolysis chars from waste and biomass,” J. Anal. Appl. Pyrolysis, vol. 49, no. 1, pp. 221-241, 1999.

[58] T. Kojima, P. Assavadakorn, and T. Furusawa, "Measurement and evaluation of gasification kinetics of sawdust char with steam in an experimental fluidized bed," Fuel Process. Technol., vol. 36, no. 1-3, pp. 201-207, 1993.

[59] Y. Chen, Handbook of fluidization and fluid-particle systems. Marcel Dekker New York, 2003.

[60] F. Scala, P. Salatino, and R. Chirone, "Fluidized bed combustion of a biomass char (Robinia pseudoacacia)," Energy Fuels, vol. 14, no. 4, pp. 781-790, 2000.

[61] F. Scala and R. Chirone, "Fluidized bed combustion of alternative solid fuels," Exp. Therm. Fluid Sci., vol. 28, no. 7, pp. 691-699, 2004.

[62] F. Scala, R. Chirone, and P. Salatino, "Combustion and attrition of biomass chars in a fluidized bed," Energy Fuels, vol. 20, no. 1, pp. 91-102, 2006.

[63] N. Jand and P. U. Foscolo, "Decomposition of wood particles in fluidized beds," Ind. Eng. Chem. Res., vol. 44, no. 14, pp. 5079-5089, 2005.

[64] J. Gil, J. Corella, M. P. Aznar, and M. A. Caballero, "Biomass gasification in atmospheric and bubbling fluidized bed: effect of the type of gasifying agent on the product distribution," Biomass Bioenergy, vol. 17, no. 5, pp. 389-403, 1999. 